4.

Derecho procesal 

Revista de Derecho

de la Pontificia Universidad Católica de Valparaíso XXXIII (Valparaíso, Chile, ${ }^{\text {do }}$ Semestre de 2009)

[pp. 263 - 302]

\title{
EL DERECHO FUNDAMENTAL A UN TRIBUNAL INDEPENDIENTE E IMPARCIAL EN EL ORDENAMIENTO JURÍDICO CHILENO*
}

["Fundamental Right to an Independent and Impartial Court in the Chilean Legal System"]

\author{
Andrés Bordalí Salamanca** \\ Universidad Austral de Chile
}

\begin{abstract}
RESUMEN
El presente trabajo analiza el reconocimiento y configuración del derecho fundamental a un tribunal independiente e imparcial en el Derecho chileno. Para determinar el contenido de este derecho el trabajo toma en consideración la jurisprudencia del Tribunal Europeo de Derechos Humanos, de la Corte Interamericana de Derechos Humanos, de los tribunales constitucionales chileno, español e italiano, así como la doctrina constitucional y procesal de estos últimos países. Teniendo presente esa jurisprudencia y doctrina, el autor realiza un análisis de la situación del derecho
\end{abstract}

\begin{abstract}
This work analyses the recognition and determination of the fundamental right to an independent and impartial court in the Chilean Law. In order to determine the content of this law, this work takes into account the jurisprudence of the European Court of Human Rights, Inter-American Court of Human Rights, the Chilean, Spanish and Italian constitutional courts, as well as the constitutional and procedural doctrines of the latter countries. Bearing in mind that jurisprudence and doctrine, the author analyses the situation of fundamental right to an independent and impartial
\end{abstract}

* Este trabajo se inscribe en el marco de una investigación más general que se está desarrollando con financiamiento del proyecto FONDECYT No 1070211 titulado "Organización y función judicial en el sistema constitucional chileno", del que el autor de este artículo es su investigador responsable. Esta investigación ha contado con la colaboración de los profesores Daniela Accatino Scagliotti y Juan Carlos Ferrada Bórquez quienes son coinvestigadores en el referido proyecto FONDECYT.

** Doctor en Derecho; Profesor de Derecho Procesal de la Universidad Austral de Chile. Dirección postal: Campus Isla Teja s/n, Casilla 567, Valdivia, Chile. Correo electrónico: abordali@uach.cl 
fundamental a un tribunal independiente e imparcial en la justicia chilena, en sus vertientes civil, penal, administrativa, militar y constitucional.

Palabras Clave: Jurisdicción - Independencia judicial - Imparcialidad - Debido proceso - Derechos fundamentales. court in the Chilean justice, in its civil, criminal, administrative, military and constitutional aspects.

KEYwORDS: Jurisdiction - Judicial independence - Impartiality - Due process - Fundamental rights.

\section{INTRODUCCIÓN}

Uno de los aspectos quizá menos desarrollados por la dogmática constitucional y procesal chilenas, en relación al debido proceso, es el referido a las garantías de independencia e imparcialidad que deben tener los jueces y tribunales.

Generalmente cuando se hace referencia al debido proceso se pone atención en la dimensión procesal de la justicia, es decir, se analizan las exigencias constitucionales que debe reunir el proceso y el contradictorio que se desarrolla entre partes, dejándose en un segundo plano las exigencias constitucionales de la organización de los juzgados y tribunales. Parece bastar, en este sentido, para que se pueda hablar de debido proceso, que ante un tribunal de justicia se permita articular un contradictorio pleno que posibilite a las partes defenderse adecuadamente para que se entienda, en términos muy generales, que se cumple con los cánones de racionalidad y justicia que impone la Constitución. Daría lo mismo, en muchos casos, cómo se elijen a esos jueces ante los cuales se desarrollará el proceso; cómo y quién puede removerlos; la duración de su encargo; si desarrolla la función de juzgar junto con otras funciones no propiamente jurisdiccionales, entre otros aspectos. Parece ser que con tal que las partes de una contienda judicial puedan alegar, probar y defenderse adecuadamente se satisfaría adecuadamente el mandato constitucional.

De conformidad con lo expuesto, surge el cuestionamiento si las personas en Chile tienen debidamente asegurado el derecho a contar con jueces independientes e imparciales. La respuesta que como hipótesis daré es negativa, pues hay varios aspectos de la jurisdicción chilena que no se compadecen con el respeto de dicha garantía. Hay materias en que la violación del derecho en cuestión es flagrante, como ocurre con las justicia militar en tiempos de paz y con la actividad jurisdiccional que desarrolla la Administración. Se trata de una justicia que carece de independencia y respecto de la cual, consiguientemente, no se puede predicar imparcialidad. 
Luego hay aspectos más sutiles y donde la jurisprudencia y doctrina no están contestes. Se trata de situaciones referidas al doble juicio que a veces pueden verse expuestos a expresar los jueces civiles y penales, como ocurre cuando un juez dicta una medida cautelar y luego debe fallar el asunto sobre el fondo, o bien cuando una corte de apelaciones se pronuncia sobre la procedencia de una medida cautelar personal y luego tiene que conocer la causa como tribunal de nulidad.

Además está la situación de los jueces civiles, de familia o laborales chilenos que están facultados para solicitar de oficio medios probatorios. Para un sector de la doctrina esos jueces dejan de ser imparciales al participar en la proposición de pruebas, juicio que expresado en esos términos no parece exacto.

Son todos estos los aspectos que la presente investigación abordará, para lo cual se analizará (II) el sentido de la expresión debido proceso en el Derecho chileno; (III) los contenidos del derecho a un tribunal independiente e imparcial que forma parte del debido proceso; (IV) las situaciones del Derecho chileno vigente que podrían comportar una vulneración del derecho fundamental a contar con jueces independientes e imparciales, para finalizar $(\mathrm{V})$ con algunas conclusiones generales.

\section{EL DERECHO FUNDAMENTAL A UN DEBIDO PROCESO}

\section{Sentido de la expresión "debido proceso" en el Derecho chileno.}

En Chile todas las personas que habitan el territorio nacional tienen reconocido un derecho fundamental a un debido proceso, pese a que no existe ninguna disposición constitucional que así lo exprese. La Constitución Politica de la República (en adelante C.Pol.) no utiliza la expresión debido proceso pero no por un olvido o un explícito deseo de no reconocer esta garantía a las personas, sino por no emplear una denominación que tiene sus orígenes en el Derecho anglosajón ("due process of law”), lo que a juicio de Evans podría haber obligado a los operadores jurídicos nacionales a interpretar la garantía a la luz de lo que la doctrina y jurisprudencia anglosajonas han construido al respecto ${ }^{1}$. Por este motivo, el constituyente de 1980 optó por usar la expresión equivalente de "racional y justo procedimiento" (artículo 19 No 3 inciso 5० C.Pol.). En esta garantía de nuestro texto constitucional hay que entender el reconocimiento del debido proceso como derecho fundamental de los ciudadanos ${ }^{2}$. Es ese, el

${ }^{1}$ Cfr. Evans, Enrique, Los derechos constitucionales (3a edición, Santiago, Editorial Jurídica de Chile, 2004), II, p. 148.

${ }^{2}$ Véase: Nogueira, Humberto, La constitucionalización del proceso: El acceso a la jurisdicción, tutela judicial efectiva o debido proceso, en FERRADA, Juan Carlos (coordi- 
debido o justo proceso, el derecho fundamental que quiso reconocer el constituyente de 1980.

¿Qué ha de entenderse por racional y justo procedimiento o debido proceso? Dicho de otro modo ¿qué garantiza el debido proceso a los habitantes del territorio nacional? Evidentemente nos encontramos con una cláusula de contenido indeterminado que debe ser colmada por el legislador o por los tribunales de justicia. La Comisión de Estudio de una Nueva Constitución (en adelante CENC), en sus sesiones $101^{\mathrm{a}}$ a $103^{\mathrm{a}}$, dejó claro que este derecho fundamental se refería a garantías tales como el emplazamiento de las partes, el examen y objeción de la prueba rendida, la existencia de recursos procesales, la fundamentación de las sentencias, etcétera, enumeración que tiene un mero sentido ejemplar, puesto que el objetivo de la cláusula "racional y justo procedimiento" era el concebir un principio de carácter constitucional que debía ser determinado en cada caso concreto por aquellos órganos competentes para realizar esa labor.

Ahora bien, nuestro texto constitucional, aparte de la criolla cláusula general del debido proceso, reconoció algunas específicas garantías que tradicionalmente han formado parte de un debido proceso, como lo son el derecho de defensa jurídica en juicio (artículo 19 No 3 inciso $2^{\circ}$ C.Pol.) y el derecho a un juez ordinario predeterminado por la ley (artículo $19 \mathrm{~N}^{\circ}$ 3 inciso $4^{\circ}$ C.Pol.). A esas garantías deben agregarse todas las otras que reconocen los tratados internacionales sobre derechos humanos ratificados por el Estado chileno y que se encuentren vigentes (artículo 5 C.Pol.). Entre esos derechos se encuentra el derecho a un tribunal competente, independiente e imparcial, entre otros, según lo reconocen la Convención Americana de Derechos Humanos (en adelante CADH.) en su artículo 8 y el Pacto Internacional de Derechos Civiles y Politicos (en adelante PIDCP.) en su artículo 14.

De conformidad con lo sostenido precedentemente, la expresión debido proceso en Chile debe referirse a específicos derechos procesales reconocidos en la Constitución de 1980 como lo son el derecho a la defensa jurídica y a un tribunal ordinario predeterminado por la ley; a específicos derechos procesales reconocidos en tratados internacionales sobre derechos humanos ratificados por el Estado chileno y que se encuentren vigentes, como lo es, entre otros, aquél referido a un tribunal competente, independiente e imparcial, y finalmente, por debido proceso puede entenderse también como un principio constitucional ${ }^{3}$ orientador de la actividad del legislador

nador), La constitucionalización del Derecho chileno (Santiago, Universidad Austral de Chile, Editorial Jurídica de Chile, 2003), p. 170.

${ }^{3}$ Véase: Zapata, Patricio, Justicia constitucional. Teoría y práctica en el Derecho chileno (Santiago, Editorial Jurídica de Chile, 2008), p. 568. Aldunate, Eduardo, 
y de los tribunales de justicia en el país.

Si entendemos que existe un principio constitucional de racionalidad y justicia en los procedimientos judiciales, es decir, nuestro debido proceso entendido como cláusula o principio general de carácter constitucional, surge la duda de si es compatible dicha cláusula de carácter general con específicos derechos procesales taxativamente reconocidos. Se podría sostener que la idea del debido proceso como un principio general de carácter constitucional tenía razón de ser antes de la reforma constitucional de 1989 que introdujo el artículo 5 C.Pol., toda vez que en la lógica original del constituyente de 1980 figuraba el criterio de no cerrar el catálogo de garantías procesales de una vez y, por el contrario, entregar al legislador y a los tribunales con competencia para velar por la supremacía constitucional la concreción de específicas garantías que sean expresión de este principio general de carácter constitucional. Sin embargo, al incorporarse un extenso catálogo de derechos procesales con la suscripción de tratados internacionales sobre derechos humanos y su inclusión al sistema constitucional chileno producto de la reforma constitucional de 1989 (artículo 5 C.Pol.), se podría pensar que la utilidad del debido proceso como principio general que necesita ser precisado en casos concretos ya no tiene sentido. Así se podría concluir que cuando se hace referencia al derecho a un debido proceso en nuestro país se alude a los específicos derechos procesales que reconocen el artículo 19 No 3 inciso $2^{\circ}$ e inciso $4^{\circ}$ C.Pol. y los tratados internacionales sobre derechos humanos (especialmente el artículo $8 \mathrm{CADH}$. y el 14 PIDCP.).

Otra interpretación posible dirá que el reconocimiento de específicos derechos procesales en el texto constitucional y en tratados internacionales sobre derechos humanos ratificados por el Estado chileno no excluye esta faceta expansiva del debido proceso como principio constitucional, que puede servir para que el legislador y los tribunales de justicia reconozcan, además, otros ámbitos de justicia de los procedimientos judiciales que no han sido expresamente abordados en la Constitución ni en los tratados internacionales sobre derechos humanos.

El debido proceso, en definitiva, funcionará como un "metaderecho" referido a un conjunto de derechos procesales mínimos más o menos detallados en la Constitución o en tratados internacionales sobre derechos humanos, pero también funciona como un principio de carácter constitucional y como un concepto jurídico indeterminado que deberá ser

Derechos fundamentales (Santiago de Chile, Legal Publishing, 2008), p. 360, sostiene que los derechos fundamentales de orden procesal se acercan más a una categoría de principios de organización y actuación jurisdiccional que a facultades subjetivas. 
precisado o colmado por los órganos a los que el sistema jurídico entregue esta competencia. En esta última concepción el debido proceso permitiría una expansión de las garantías mínimas reconocidas en la Constitución o los tratados internacionales. Veremos a continuación quién podría desarrollar esa labor expansiva de las garantías procesales de las personas.

\section{El debido proceso frente al legislador y a los tribunales de justicia.}

En doctrina se ha discutido la naturaleza de los derechos fundamentales de contenido procesal o del derecho al debido proceso. Así algunos no dudan en calificarlo como derecho prestacional ${ }^{4}$, lo que expresaría que el derecho debe ser configurado por el legislador. Se habla también a veces de derechos de configuración legal ${ }^{5}$. Se trataría en concepto de Alexy ${ }^{6}$ de derechos a prestaciones en un sentido amplio que comportarían un derecho a acciones positivas normativas por parte del Estado, a diferencia de los derechos a prestaciones en sentido estricto que reclaman acciones fácticas por parte del Estado (derechos sociales). Para que el derecho prestacional surta efectos prácticos en el ordenamiento jurídico se requiere que el legislador lo desarrolle dictando la o las leyes que correspondan.

Sin embargo, esta concepción del derecho prestacional podría dar lugar a dos tipos de problemas. En primer lugar se debe determinar qué sucedería en casos de inactividad del legislador. ¿Frente a una actitud pasiva del legislador puede entenderse que el derecho fundamental existe y ser invocado por los particulares? En segundo lugar aparece el problema de los límites que tiene el legislador para configurar el derecho. ¿Puede darle el sentido que estime pertinente el legislador al derecho?

En relación al primer problema se debe constatar que no hay herramientas jurídicas que obliguen al legislador a actuar para dar vida a un determinado derecho. Este problema de la inactividad legislativa puede comprender dos situaciones diferentes. En primer lugar está el caso de un legislador radicalmente pasivo que no ha dictado nunca una disposición legal que le dé vida al derecho fundamental. En segundo lugar está el caso de un legislador que ha dictado disposiciones legales pero que respecto a un derecho fundamental en particular ha omitido aspectos.

Respecto a la pasividad radical, es decir, que no haya ninguna ley que se refiera al derecho fundamental en cuestión, la verdad es que se trataría de una hipótesis muy marginal difícil de concebir en la realidad. Y si existe una

\footnotetext{
${ }^{4}$ Véase: Nogueira, Humberto, cit. (n. 2), p. 175.

${ }^{5}$ Véase: JimÉnez AsEnsio, Rafael, Imparcialidad judicial y derecho al juez imparcial (Pamplona, Aranzadi, 2002), p. 307.

${ }^{6}$ Cfr. Alexy, Robert, Teoría de los derechos fundamentales (Madrid, Centro de Estudios Constitucionales, 1997), p. 195 ss.
} 
situación del género la solución pasaría por una presión política o ciudadana hacia el Congreso Nacional para que legisle al respecto, sin descartar que se pueda intentar presiones a través de organismos internacionales o bien por medio de demandas ante tribunales internacionales, como podría ser en nuestro caso ante la Corte Interamericana de Derechos Humanos (en adelante $\mathrm{CIDH}$ ) para que el Estado de Chile se vea obligado a actuar con el fin de dar cumplimiento a lo ordenado por el fallo y brindar así amparo al derecho fundamental reconocido por el tratado internacional.

Las hipótesis más realistas son las segundas, es decir, que existan leyes relacionadas con el derecho fundamental en cuestión pero omiten aspectos referidos a él, como sucedería en nuestro caso con todas las leyes de orden procesal vigentes que, por ejemplo, no reconocieran el derecho a contradecir, a aportar los medios de prueba, etc. En algunos países ${ }^{7}$ han resuelto este problema a través de especiales tipos de sentencias pronunciadas por las cortes constitucionales como son las denominadas sentencias manipulativas, integrativas o aditivas, donde la corte constitucional declara inconstitucional una disposición legal en la medida que ha omitido decir algo que la Constitución le prescribía.

El Tribunal Constitucional chileno parece no estar en esta línea ${ }^{8}$. Esta negativa a la declaración de inconstitucionalidad de una ley que no reconoce o desarrolla adecuadamente un derecho fundamental deriva entre otras razones de la jurisprudencia de nuestro Tribunal Constitucional en orden a que la inconstitucionalidad afecta a preceptos determinados y no a un proyecto de ley o a una ley en su integridad ${ }^{9}$. Así, la declaración de inconstitucionalidad por omisión sólo podría tener cabida cuando se impugnara el proyecto o la ley in toto, lo que no es aceptado por nuestro Tribunal Constitucional.

Ahora bien, nada de ello parecería obstar entre nosotros a que se invoque el derecho fundamental ante la judicatura pese a que no hay ley que lo desarrolle. Para ello podría invocarse el artículo 6 C.Pol., es decir, se apelaría a una aplicación directa de la Constitución.

${ }^{7}$ Para el caso austriaco, véase: SCHÄFFER, Heinz, p. 17; para el caso italiano RoMBOLI, Roberto, pp. 113 ss.; para el caso portugués NunES DE ALMEIDA, Luis, pp. 238 ss., todos en AJA, Eliseo (editor), Las tensiones entre el Tribunal Constitucional y el Legislador en la Europa actual (Barcelona, Ariel, 1998).

${ }^{8} \mathrm{Un}$ interesante caso conocido por el Tribunal Constitucional chileno en que se discutió si la vulneración del derecho fundamental a la tutela judicial de las víctimas por delito (artículo 83 inciso $2^{\circ}$ C.Pol.) se veía afectado por una disposición legal (artículo 230 CPP.) o bien por una omisión del legislador, puede verse en la causa sobre inaplicabilidad rol No 815-07 de fecha 19 de agosto de 2008.

${ }^{9}$ Véase: Aldunate, Eduardo, cit. (n. 3), p. 201. 
Sin embargo, más allá de que la aplicación directa de la Constitución sea una tesis ampliamente aceptada en nuestra doctrina ${ }^{10}$, por lo que todo tribunal de justicia -sostendría esta doctrina- podría aplicar directamente un derecho fundamental aun a falta de ley reguladora o aun contra ley reguladora, lo cierto es que hay instrumentos procesales en nuestro sistema jurídico que permitirían a determinados tribunales darle aplicación a un derecho fundamental sin que exista ley reguladora del mismo. Este es el caso, por ejemplo, de la facultad que tiene la Corte Suprema en un juicio penal para dejar sin efecto el juicio y la sentencia del Tribunal de juicio oral en lo penal cuando se afectare el debido proceso de los condenados por delito ${ }^{11}$ en la investigación criminal a cargo del Ministerio Público o en el juicio penal. Para tal fin la Corte Suprema apelará al reconocimiento de este derecho en la Constitución y los tratados Internacionales sobre derechos fundamentales que hayan sido suscritos por el Estado chileno y se encuentren vigentes (artículo 373 letra a) CPP.). Similar situación contempla el artículo 477 del Código del Trabajo vigente en algunas regiones del país.

En ambas situaciones se trata de casos en que el legislador ha previsto la nulidad del juicio por afectación de derechos constitucionales, donde se podría producir una invocación directa de la Constitución. Es decir, en estos casos la aplicación directa de la Constitución se realiza por una decisión del legislador, pero no por una garantía constitucional exigible al legislador.

Esto viene a significar que en su comprensión estrictamente constitucional el debido proceso se comporta como un derecho prestacional que obliga al legislador a desarrollar el derecho (status positivo en la conocida clasificación de Jellinek), pero también, según los Códigos Procesal Penal y del Trabajo chilenos, como un status negativo o una libertad frente al Estado $^{12}$ (frente al Ministerio Público, policías, jueces penales o jueces laborales).

${ }^{10}$ Por todos, véase: Fernández, Miguel Ángel, Constitución y casación: ¿De la falta de aplicación al monopolio constitucional?, en Estudios Constitucionales. Revista del Centro de Estudios Constitucionales, 3 (2005) 1, p. 110.

${ }^{11}$ No existe espacio acá para discutir si el derecho fundamental a un debido proceso penal pertenece a todos los intervinientes del enjuiciamiento criminal, incluido por tanto el Ministerio Público, o bien sólo correspondería a los imputados, acusados o condenados por delito. Sobre este aspecto, véase: Aldunate, Eduardo, cit. (n. 3), p. 157.

${ }^{12}$ En el Derecho español se sostiene por un sector de la doctrina que el derecho fundamental a la tutela judicial efectiva y el debido proceso participan de la naturaleza de status negativo como del status positivo, es decir, como libertad frente al Estado y como pretensión frente al Estado. Véase: BANdrés SÁnCHEZ - CruZat, José Ma- 
En relación al problema de la libertad de configuración por parte del legislador, hay que constatar que no es posible exigir al legislador que establezca específicas reglas procesales de desarrollo de un debido proceso. El peligro que se produce en este caso es que el derecho fundamental queda disponible para el legislador pudiendo establecer los requisitos, contenidos y condicionamientos que estime necesarios, por lo que el debido proceso perdería su garantía constitucional. En este caso al legislador no se le puede exigir que regule el derecho de determinada manera pero sí que no lo haga de la manera en que lo ha hecho. Se podría controlar el respeto del debido proceso atacando la ley procesal cuando ha transgredido el contenido esencial del derecho ${ }^{13}$. Dicho ataque de la ley procesal podrá ser realizado preventivamente en la etapa de formación de la ley o bien a través de los medios de control represivo, según las competencias que actualmente regula para el Tribunal Constitucional el artículo 93 C.Pol..

Este control del legislador por parte de los órganos de la justicia constitucional fue la primera idea protectora del debido proceso en la génesis de la Constitución de 1980. En efecto, la CENC, en su sesión 102a, estimó que quien debía colmar el principio del debido proceso debía ser el legislador. Asimismo, ideó que la Corte Suprema como tribunal competente para conocer de la inaplicabilidad de las leyes, es decir, como corte materialmente constitucional, debía ser el órgano capaz de controlar si el legislador estaba regulando los procedimientos judiciales de acuerdo a un canon de racionalidad y justicia, o, lo que es lo mismo, según exigencias de un debido proceso. La inaplicabilidad de las leyes debía servir a estos efectos de dos vías diferentes. Una vía de control en el sentido que el legislador no conculcara los derechos de los justiciables de carácter procesal y una segunda consistente en la formación de una jurisprudencia que delineara el contenido de este derecho constitucional. Con esta opción se quiso evitar que se controlara a los tribunales de justicia en sus decisiones judiciales sobre el respeto o no del debido proceso en los casos concretos. La Corte Suprema no debía controlar las decisiones de los tribunales inferiores sino sólo al legislador.

Tenemos así que el Tribunal Constitucional es el órgano con competencia para controlar que el legislador respete el debido proceso configurado en las leyes. Lo mismo puede hacer este tribunal respecto de esa labor "cuasi legislativa” desarrollada por la Corte Suprema, las cortes de apelaciones y el

nuel, Derecho fundamental al proceso debido y el Tribunal Constitucional (Pamplona, Aranzadi, 1992), p. 102.

${ }^{13}$ Véase: Aldunate, Eduardo, cit. (n. 3), p. 201; Bandrés SÁnchez - Cruzat, José Manuel, cit. (n. 12), p. 310; Colmenero, Miguel, La garantía del derecho a un juez imparcial, en Persona y Derecho 55 (2006), p. 724. 
Tribunal Calificador de Elecciones mediante autos acordados, en la medida que pudieren afectar el debido proceso de los justiciables (artículo 93 No 2 C.Pol.). Se trata de un control de actuaciones positivas de esos legisladores. Por otra parte, corresponde a la Corte Suprema y a las cortes de apelaciones en algunos casos controlar que los tribunales inferiores (penales o laborales) o algunos sujetos del enjuiciamiento criminal (Ministerio Público y policías) respeten con sus actuaciones el debido proceso de los justiciables. En este caso el control puede recaer sobre actuaciones positivas de estos órganos o bien por omisiones, con tal que ambas produzcan una conculcación del debido proceso de los justiciables de una causa concreta.

Todo el razonamiento precedente debe ser aplicado al derecho fundamental a un tribunal independiente e imparcial.

\section{CONTENIDOS DEL DERECHO FUNDAMENTAL A UN TRIBUNAL INDEPENDIENTE E IMPARCIAL}

\section{El derecho a un juez imparcial: Imparcialidad subjetiva y objetiva de los jueces.}

Quizá el mayor desarrollo del contenido de un derecho a un tribunal independiente e imparcial proviene de la jurisprudencia del Tribunal Europeo de Derechos Humanos (en adelante TEDH). Particularmente, en relación al artículo 6.1 del Convenio europeo para la protección de los derechos humanos y de las libertades fundamentales (en adelante el Convenio Europeo), esta corte ha juzgado el requisito de la imparcialidad de los jueces, entendiendo que esta tiene una vertiente subjetiva y otra objetiva.

La imparcialidad considerada subjetivamente dice relación con el posicionamiento personal de los jueces en los términos de las partes de una causa judicial. Se habla de una consideración del fuero interior de los jueces, que debe considerarse imparcial mientras no se demuestre lo contrario ${ }^{14}$. Se ha dicho que la imparcialidad subjetiva, cual derecho fundamental de los justiciables, comporta una garantía que permite que un juez sea apartado de un caso concreto cuando existan sospechas objetivamente justificadas. Es decir, debe tratarse de conductas exteriorizadas y apoyadas en datos objetivos que permitan afirmar que el juez no es ajeno a la causa o que permitan temer que, por cualquier relación con el caso concreto, no utilizará como criterio de juicio el previsto por la ley sino otras consideraciones ajenas al ordenamiento jurídico ${ }^{15}$. El criterio subjetivo ha sido

${ }^{14}$ Véase: Ubertis, Gulio, Principi di procedura penale europea. Le regole del giusto processo (2a edición, Milano, Raffaello Cortina, 2009), p. 35.

${ }^{15}$ Véase: Pedraz, Ernesto, Derecho procesal penal, I: Principios de Derecho procesal penal (Madrid, Colex, 2000), p. 213. 
declarado por el TEDH en sentencias como la de 26 de octubre de 1984 en la causa "De Cubber contra Bélgica", y luego en otras como "Fey" de 24 de febrero de 1993, "Remli", de 23 de abril de 1996 y "Gregory", de 25 de febrero de 1997.

Corresponderá a la parte que se lamenta de la parcialidad del magistrado demostrarla, probando en concreto que la disposición anímica o psicológica del juez y su conducta exteriorizada son síntomas de falta de imparcialidad.

La jurisprudencia del TEDH ha influido asimismo a algunas cortes constitucionales europeas. Así, El Tribunal Constitucional español, por sentencia 162 de 1999, recogiendo esta línea divisoria abierta por el TEDH, ha expresado que la perspectiva subjetiva de la imparcialidad trata de apreciar la convicción personal del juez, lo que pensaba en su fuero interno en tal ocasión, a fin de excluir a aquél que internamente haya tomado partido previamente o vaya a basar su decisión en prejuicios indebidamente adquiridos.

Por otra parte, la imparcialidad considerada objetivamente toma en consideración la relevancia de aquellas condiciones exteriores que pueden comprometer o perjudicar la administración imparcial de la justicia ${ }^{16}$. En esta perspectiva importa mucho la apariencia de imparcialidad de los jueces. La imparcialidad objetiva apunta también a la necesaria confianza que los órganos judiciales deben dar a los ciudadanos y, sobre todo, a los acusados por delito ${ }^{17}$. Sentencias relevantes en esta materia del TEDH son las de fecha 24 de mayo de 1989 ("Hauschildt con Dinamarca") y la de fecha 25 de junio de 1992 ("Thorgeir Thorgeirsen con Islandia").

Con la imparcialidad objetiva no se trata ya que el juez haya exteriorizado convicción personal alguna ni haya tomado partido previo, sino que estamos frente a un juez que no ofrece garantías suficientes para excluir toda duda legítima al respecto. Por eso, en esta perspectiva, importan sobremanera las consideraciones de carácter funcional y orgánico, pues determinan si, por las funciones que se le asignan al juez en el proceso, puede este ser visto como un tercero ajeno a los intereses que en él se ventilan ${ }^{18}$.

Cuando se separa a un juez de la causa porque se ha tomado en consideración la ausencia de imparcialidad objetiva, no debe entenderse como una constatación de su parcialidad, sino como una medida adoptada con

${ }^{16}$ Véase: Comoglio, Luigi Paolo, Etica e tecnica del "giusto processo" (Torino, Giappichelli, 2004), p. 77.

${ }^{17}$ Véase: Ubertis, Giulio, cit. (n. 14), p. 35.

${ }^{18}$ Véase: LoREdo, Marcos, Comentarios prácticos a la Ley de Enjuiciamiento Civil. La imparcialidad en el proceso civil: el deber de abstención. Arts. 99, 100 y 102 a 106 LEC, en INDRET (Mayo 2009), p. 5. 
un carácter de prevención, para así eliminar recelos y sospechas, evitando una eventual posterior acusación de parcialidad ${ }^{19}$.

Sin embargo, no siempre es fácil distinguir entre imparcialidad subjetiva y objetiva, la cuales no siempre pueden separarse netamente ${ }^{20}$. Hay un sector de la doctrina que sostiene que los problemas de imparcialidad siempre deben llevarse al plano de la subjetividad. Se ha dicho así que "las tachas de parcialidad por mucho que se objetiven conducen casi siempre a situar el problema en las circunstancias subjetivas del juzgador" ${ }^{21}$. Una clara posición contra el criterio objetivo de la imparcialidad es la que manifiestan Montero Aroca y Flors ${ }^{22}$, quienes sostienen que la imparcialidad es siempre subjetiva, pues dice relación siempre con la equidistancia que debe tener todo juez respecto de las partes y el objeto del proceso. Afirmaciones como las sostenidas por el TEDH en el sentido que respecto a la imparcialidad las apariencias pueden tener importancia o aquella que sostiene que no sólo hay que hacer justicia, sino que ha de parecer también que se hace, son a juicio de esta doctrina "mera literatura"23.

De conformidad con todo lo dicho, corresponde examinar con más detalle qué tipo de situaciones podrían comportar falta de imparcialidad de los jueces, ya sea una exteriorización de la psiquis, ideología o intereses del juez o ya una regulación de la función del juez que no permite presuponer imparcialidad. En todo ello importará determinar si se entiende que las situaciones que comportan falta de imparcialidad de los jueces o no las determinará en exclusiva el legislador o si los jueces (generalmente superiores) podrán ir más allá de lo que haya dispuesto la ley, haciendo una aplicación directa de la Constitución. Esto quiere decir, aplicado al Derecho chileno, si los jueces podrán ser apartados de una causa sólo por aplicación de las causales de implicancia o recusación que prevé el Código Orgánico de Tribunales, o bien los jueces que conocen de la inhabilitación de los mismos podrían considerar otras causas diferentes. Luego habrá de determinarse si sólo se considerará la falta de imparcialidad en una faceta estrictamente subjetiva, o bien también se considerarán cuestiones relacionadas con la regulaciones orgánicas y funcionales de los jueces que permitan hablar de prejuicios por parte del juzgador, como sucede con todos aquellos casos en que el juzgador ya se ha pronunciado sobre el mismo asunto. A continuación desarrollaré esta discusión.

\footnotetext{
${ }^{19}$ Véase: LoRedo, Marcos, cit. (n. 18), p. 6.

${ }^{20}$ Véase: Ubertis, Giulio, cit. (n. 14), p. 35.

${ }^{21}$ JiméneZ Asencio, Rafael, cit. (n. 5), p. 193.

${ }^{22}$ Cfr. Montero Aroca, Juan - Flors, José, Amparo constitucional y proceso civil

( $2^{a}$ edición, Valencia, Tirant lo Blanch, 2008), pp. 139 ss.

${ }^{23}$ Montero Aroca, Juan - Flors, José, cit. (n. 22), p. 142.
} 


\section{2. ¿Quién define la falta de imparcialidad en un Estado Constitucional de Derecho?}

Se discute en algunos ordenamientos si las causas o los mecanismos para apartar a un juez de una causa por considerarse que no es imparcial, son las que reconoce el legislador a través de los mecanismos de abstención o implicancias y la recusación o bien podemos ir más allá de lo que haya dispuesto expresamente el legislador. Si se sostiene que estas causales sólo son las dispuestas por el legislador, mantenemos el asunto en un plano de pura legalidad y no de constitucionalidad. Sin embargo, en países como España se ha sostenido que aun cuando se opte por una tesis tasada por el legislador de estas causales, es decir, la falta de imparcialidad es la que disponga expresamente el legislador, el Tribunal Constitucional igualmente podría controlarlas ${ }^{24}$.

Un sector de la doctrina española critica seriamente la concepción de las causas legales de la imparcialidad, pues equivaldría a sostener que lo que sea el contenido concreto del derecho fundamental al juez imparcial lo determina a su antojo el legislador. Y esto se ve especialmente agravado en países como España y Chile, pues en ellos las implicancias y recusaciones son situaciones que se han conformado legislativamente durante el siglo XIX, no poniéndose atención en que el contexto presente en el que se desenvuelve la función judicial ha cambiado sustancialmente ${ }^{25}$.

Si miramos la situación de nuestro Derecho patrio, surgen dudas si los artículos 195 y 196 del Código Orgánico de Tribunales contemplan dentro de las causales de implicancia y recusación situaciones que son de mayor ocurrencia en la sociedad contemporánea caracterizada por un mayor pluralismo ético, ideológico y político. ¿Qué sucedería si las partes consideran causa de parcialidad el que un juez forme parte de una determinada organización religiosa? ¿Qué pasaría si el juez ha manifestado en la causa comentarios sexistas o racistas? ¿Qué pasa si el juez ha manifestado de cualquier modo una cierta inclinación política?

El único precepto de nuestro Código Orgánico de Tribunales que podría dar relativa cabida a situaciones como las acá planteadas es el artículo 196 No 15, que establece como causa de recusación: "Tener el juez con alguna de las partes enemistad, odio o resentimiento que haga presumir que no se halla revestido de la debida imparcialidad'. Es evidente que no hay referencias expresas a cuestiones como las acá planteadas. ¿Qué hacer en estos casos? Las alternativas son dos: $\mathrm{O}$ se hace una interpretación extensiva del numeral 15 , asumiendo de esta manera la causal una función de "cajón de sastre",

\footnotetext{
${ }^{24}$ Véase: LoREdo, Marcos, cit. (n. 18 ), p. 7

${ }^{25}$ Véase: Jiménez Asensio, Rafael, cit. (n. 5), pp. 300 ss.
} 
donde entrarían las cuestiones de parcialidad como las expuestas acá, o bien debe entenderse que los jueces están facultados para considerar otras causales de parcialidad fuera de los casos previstos por la ley.

Es probable que esta última propuesta no pueda ser invocada cuando se plantee un incidente referido a implicancias o recusaciones. El artículo 113 del Código de Procedimiento Civil es bastante claro a este respecto: "Sólo podrá inhabilitarse a los jueces y a los auxiliares de la Administración de Justicia para que intervengan en un negocio determinado, en los casos y por las causas de implicancia o recusación que señala el Código Orgánico de Tribunales". Y esa parece ser la regla en todo tipo de procedimientos.

Sin embargo, la situación es distinta en los casos cuando se pide la nulidad de un juicio y la sentencia por afectar el debido proceso, como ocurre hoy en día en materia procesal penal y laboral. Si tomamos la experiencia procesal penal, la Corte Suprema podría declarar nulos un juicio y la sentencia penal por considerar que el juez de garantía o el tribunal de juicio oral en lo penal han tenido conductas que no se avienen con el derecho fundamental a un tribunal independiente e imparcial que la Constitución y los tratados internacionales reconocen al condenado por delito. Esa declaración de nulidad, por aplicación del artículo 373 letra a) CPP., no tiene por qué estar sujeta a las causas de implicancia y recusación que haya dispuesto el Código Orgánico de Tribunales en sus artículos 195 y 196. La Corte Suprema estaría sujeta a la Constitución y a los tratados Internacionales en esta materia, pues así lo ha querido el legislador procesal penal. Podría así estimar la Corte Suprema que el juez de garantía o el tribunal de juicio oral en lo penal han tenido, por ejemplo, actitudes sexistas o racistas contra el condenado, situación que afectaría a su imparcialidad para fallar el asunto, aunque tales causales no están expresamente previstas en la ley orgánica de tribunales.

El problema radicaría entonces en las causales legales para pedir durante un procedimiento judicial en curso la inhabilidad de un juez, las que al día de hoy sólo sean las de los artículos 195 y 196 COT. Desde un punto de vista de lege ferenda, se hace recomendable que el legislador amplíe las causas de inhabilidad de los jueces contempladas en los artículos $195 \mathrm{y}$ 196 COT., lo que podría significar adoptar dos caminos diversos. Una primera posibilidad pasa por reconocer expresas causales como las referidas a los tópicos precedente señalados (prejuicios religiosos, raciales, sexistas, etcétera). Otra posibilidad es la introducción de causales más elásticas al estilo de la "remisión del proceso por legítima sospecha" del artículo 45 CPP. italiano, que podría afectar al órgano judicial en su conjunto y no al juez individualmente considerado, lo que en la jurisprudencia de la casación italiana se ha interpretado restrictivamente, configurable sólo cuando se 
está en presencia de una grave y objetiva situación local, entendida como fenómeno externo a la dialéctica procesal, capaz de constituir un peligro concreto para la imparcialidad del juez ${ }^{26}$.

Otro camino es la recusación por motivo serio y grave capaz de generar desconfianza sobre la imparcialidad del juez que regula el artículo 43.1 del Código de Proceso Penal portugués. Parece ser ésta una alternativa que combina adecuadamente tipicidad de la figura pero acompañada de flexibilidad para adaptarse a los cambios culturales y para entregar siempre a los justiciables la posibilidad de apartar a un juzgador del que se sospeche parcialidad.

\section{La incompatibilidad como manifestación de la imparcialidad objeti-} va.

Algunos ordenamientos jurídicos contemplan causales de inhabilitación de los jueces por configurarse algunas situaciones que hacen presumir falta de imparcialidad pero no por existir entre el juez y las partes alguna conexión o interés, o bien entre el juez y el objeto litigioso, sino por desarrollar funciones que pueden significar conocer más de una vez el asunto por parte de ese juez.

El TEDH se ha pronunciado en varias oportunidades sobre estas situaciones que denominaré genéricamente incompatibilidad. El Derecho italiano las reconoce abiertamente y nuestro Código Orgánico de Tribunales también reconoce algunas hipótesis de incompatibilidad. En efecto, el artículo 195 COT. en su apartado final establece que respecto de los jueces con competencia criminal, son causas de implicancia, además, las siguientes: i) Haber intervenido con anterioridad en el procedimiento como fiscal o defensor; ii) Haber formulado acusación como fiscal, o haber asumido la defensa, en otro procedimiento seguido contra el mismo imputado; y iii) Haber actuado el miembro del tribunal de juicio oral en lo penal como juez de garantía en el mismo procedimiento.

En doctrina se ha entendido que las situaciones de incompatibilidad complementan la garantía de contar con un juez independiente e imparcial, como ocurre en aquellos casos en que se acumulan en la persona del magistrado funciones, actividades $\mathrm{u}$ oficios objetivamente inconciliables con el ejercicio de la función jurisdiccional. También está la situación del juez que haya cumplido en el mismo procedimiento actos previos de ejercicio de la función, los que deben considerarse inconciliables con el deber de conocer después el asunto con plena serenidad y en condiciones

${ }^{26}$ Sentencia de las secciones unidas penales de la Corte de Casación italiana, de fecha 27 de enero de 2003. 
de absoluta carencia de prejuicios personales. Debe tratarse en este último caso de diversas fases del procedimiento, de modo tal que no incurre en alguna incompatibilidad aquel juez que en el contexto de la misma fase procesal haya debido expresar valoraciones preliminares, aunque sean de mérito, destinadas a desembocar en la decisión conclusiva ${ }^{27}$.

La Corte Constitucional italiana (sentencia rol No 155 de 1996) ha señalado que la imparcialidad reclama que la función de juzgar sea asignada a un sujeto "tercero" no sólo en el sentido de carecer de intereses propios, sino también desprovisto de convicciones preconstituidas sobre la materia a decidir, las que pueden haberse formado en las diversas fases del juicio con ocasión de funciones decisorias que él ha debido desarrollar precedentemente. La función jurisdiccional, agrega esta corte, se caracteriza por su objetividad, lo que exige la máxima despersonalización del ente juzgador. Se trata que el juzgador pueda fallar el asunto sólo atendiendo a una racional apreciación de las pruebas aportadas al proceso, sin que se vea influenciado por valoraciones sobre el mérito precedentemente expresadas (sentencia Corte Constitucional italiana rol No 177 de 1996).

Como se ha indicado precedentemente, para configurarse la incompatibilidad debe tratarse de valoraciones efectuadas por el juez o tribunal en distintas fases del procedimiento. Es decir, no habría incompatibilidad si en la fase de decisión definitiva un juez que pertenece a un colegio juzgador da una primera opinión en el procedimiento de formación de la convicción definitiva. Descartada este tipo de situaciones, las hipótesis más comunes donde puede darse este caso de incompatibilidad ocurre con aquel juez que investiga y luego falla el asunto o el caso del juez que decreta una medida cautelar y luego falla el asunto. Los artículos 34 y 35 CPP. italiano expresamente prevén esta situación.

Un sector de la doctrina sostiene que el problema de la incompatibilidad no es un problema de parcialidad sino de ejercicio indebido de la función jurisdiccional. Así Montero Aroca y Flors expresan que la exigencia de imparcialidad apunta a que en el ánimo del juez al conocer y decidir un asunto no influyan circunstancias que lo puedan llevar a inclinarse por una de las partes o a decidir conforme a su propio interés. En este sentido, expresan, no afecta realmente a la imparcialidad el prejuicio, esto es, el decidir habiéndose formado una convicción previa, no a favor o en contra de una de las partes o de su propio interés, sino sobre el contenido de la resolución a dictar. Las hipótesis de incompatibilidad, dice esta doctrina,

${ }^{27}$ Véase: Comoglio, Luigi Paolo, cit. (n. 16), pp. 76 ss. 
lo que hacen es impedir que el juez forme su convicción en el modo previsto en la ley ${ }^{28}$.

¿Por qué se considera que la incompatibilidad puede producir parcialidad de juicio? El juez que ha prejuzgado se puede ver compelido luego en la fase decisoria a mantener su posición. Es lo que en el Derecho italiano se denomina "fuerza de la prevención" ${ }^{29}$. En este sentido, quizá de un modo bastante amplio, puede sostenerse que este juez ha fallado tutelando su propio interés antes que lo que exigiría en ese caso la ley, por lo que podría ser considerado parcial. ¿Por qué se dice que el juez hace primar su propio interés? Porque existiría una natural tendencia de toda persona a no cambiar sus propias ideas o, dicho positivamente, a mantener sus juicios, o bien a no reconocer sus culpas, más encima si eso puede traerle sanciones ${ }^{30}$. Un juez debe juzgar a las partes y no a sí mismo ("nemo iudex in causa propia") y un juicio sobre sí mismo se daría cada vez que un juez es llamado a juzgar nuevamente un hecho que ya ha valorado precedentemente ${ }^{31}$.

Un juez que durante el procedimiento ha valorado la existencia de una apariencia de derecho ("fumus boni iuris"), decretando una medida cautelar, podría verse condicionado ya por mecanismos psicológicos (no mostrarse contradictorio), sociales (evitar la crítica pública) o jurídicos (exponerse a sanciones) para mantener esa valoración al momento en que debe fallar el asunto en su mérito, aunque de las alegaciones de las partes y las pruebas introducidas al proceso se forme otra convicción. En este caso, el juez más que aplicar la ley al caso concreto, mantendría su opinión formada previamente y en tal sentido juzga según su propio interés. Ese juez carecería de la debida imparcialidad.

${ }^{28}$ Cfr. Montero Aroca, Juan - Flors, José, cit. (n. 22), p. 139. Se dice en otras ocasiones que nada tiene que ver con la garantía constitucional de la "terzietà" e imparcialidad del juzgador, situaciones como las de un juez civil que provee un secuestro o una providencia de urgencia y luego falla sobre el mérito de la causa. Véase: Chiarloni, Sergio, Il nuevo articolo 111 della Costituzione e il processo civile en Civinini, Maria Giuliana - Verardi, Carlo Maria (editores) Il nuevo articolo 111 della Costituzione e il giusto processo civile (Milano, Franco Angeli, 2001), p. 32.

${ }^{29}$ Sobre la denominada "fuerza de la prevención", véase: Bove, Mauro, Artículo 111 cost. E "giusto processo civile”, en Rivista di Diritto Processuale 57 [2a serie] (abriljunio de 2002) 2, p. 508; Perchinunno, Francesco, Fondamento del giusto processo: Dalle origini all attuazione (Bari, Cacucci, 2005), pp. 144 ss.; Comoglio, Luigi Paolo, cit. (n. 16), p. 78.

${ }^{30}$ Véase: Chiarloni, Sergio, cit. (n. 28), p. 27; Andolina, Italo - Vignera, Giuseppe, I fondamenti costituzionali della giustizia civile. Il modelo costituzionale del processo civile italiano (2a edición, Torino, Giappichelli, 1997), pp. 43 ss.

${ }^{31}$ Véase: RoiAti, Alessandro, Cause di estromissione personale del giudice e rimessione del processo (Padua, Cedam, 2007), p. 9. 
Un sector de la doctrina ${ }^{32}$ rechazará esta falta de imparcialidad entre el juez que decreta una medida cautelar y luego falla debido a la diferencia esencial entre ambas valoraciones, ya que se trata de juicios completamente diferentes. No existe la misma res iudicanda, toda vez que la medida cautelar se decreta con base a un juicio de probabilidad sobre la existencia del derecho, es decir, el juez falla articulando un contradictorio muy reducido de carácter sumario y provisorio, y la sentencia definitiva tendrá en consideración un contradictorio pleno con alegaciones y pruebas para determinar la existencia efectiva del derecho.

Ahora bien, sin perjuicio que es evidente que se trata de formas de conocer muy diferentes y por lo tanto no se puede decir que exista una misma res iudicanda, lo cierto es que igualmente puede producirse la denominada "fuerza de la prevención".

El TEDH en general ha rechazado las alegaciones formuladas por ciudadanos europeos respecto de la situación que se da cuando es el mismo juez el que decreta una medida cautelar y luego falla sobre el mérito. No ha considerado el tribunal de Estrasburgo que se afecte la imparcialidad de estos jueces. Así lo falló en la causa "Hauschildt contra Dinamarca", de fecha 24 de mayo de 1989.

En general los legisladores y cortes han considerado que esta incompatibilidad entre el juez que dicta una medida cautelar y luego falla sobre el mérito de la causa sólo es exigible en sede penal y no en el resto de los órdenes jurisdiccionales. Hay valoraciones sobre lo específico del juicio cautelar en sede penal (medidas cautelares personales) que lo diferencia de los otros órdenes jurisdiccionales ${ }^{33}$.

Por otra parte, es claro que cuestiones de orden práctico también han aconsejado no declarar ilegítimo que un mismo juez civil que decreta una medida cautelar luego falle el fondo del asunto. Separar el juicio cautelar del juicio de fondo podría significar retardar aun más la respuesta jurisdiccional al tener que formar de otro modo al órgano juzgador, con clara violación de la garantía fundamental como lo es el derecho a una respuesta judicial dentro de un plazo razonable. Separar la decisión cautelar de la de mérito comportaría introducir una complejidad procesal que a veces resultaría atentatoria con la necesidad de respuestas judiciales oportunas y eficientes, y desde luego un peso extraordinario para el erario público. El peligro de la fuerza de la prevención como posible daño para la imparcialidad judicial ha cedido en muchas oportunidades a favor de otros principios y derechos procesales.

\footnotetext{
${ }^{32}$ Véase: Perchinunno, Francesco, cit. (n. 29), p. 146.

${ }^{33}$ Sobre este razonamiento, véase: Chiarloni, Sergio, cit. (n. 28), pp. 27 ss.
} 


\section{El derecho a un juez independiente.}

Independencia e imparcialidad deben ser consideradas como situaciones conectadas pero con sustantividades diferentes. Un juez que es amigo de una de las partes del juicio podrá ser considerado parcial en esa causa pero no necesariamente falto de independencia. La independencia se refiere a un aspecto o faceta más estática u orgánica frente a lo funcional o procesal que implica la imparcialidad. Dicho de otro modo, la independencia se relaciona con la doctrina de la separación de poderes y con la autonomía para juzgar de todo juez dentro de la estructura judicial interna. La imparcialidad a su vez dice relación con posibles relaciones del juez con las partes de la causa o con el objeto litigioso. Se trata de dos aspectos claramente relacionados pero diversos, salvo que se use el término independencia de manera muy amplia comprendiendo también la ausencia de condicionamientos psicológicos y de todo otro tipo ${ }^{34}$.

Es evidente que para poder garantizar una justicia imparcial los ciudadanos deben contar también con la garantía de la independencia de los jueces. Una persona dependiente de otro sujeto o poder o un juez que deba responder de la actividad lícitamente cumplida frente a otro no podría poseer los debidos requisitos de imparcialidad. De este modo, la independencia de los jueces constituye una condición de existencia de la imparcialidad.

Para el TEDH asume especial relevancia para garantizar la independencia judicial el modo de designación de los jueces y la duración del mandato judicial, así como la existencia de previsiones normativas idóneas para tutelar al órgano jurisdiccional contra presiones externas, según se concluye de la sentencia de esta corte europea de fecha 1 de octubre de 1982, caso "Piersack contra Bélgica". Especial relevancia tiene además la inamovilidad de los jueces que se considera un corolario de su independencia y, por lo tanto, garantizado por el artículo 6.1 del Convenio Europeo, según se extrae de la sentencia del TEDH de fecha 28 de junio de 1984, en el caso "Campbell y Fell con Reino Unido".

Uno de los problemas más relevantes presentados en el Derecho europeo con relación a la falta de independencia de los jueces y, por lo tanto, como posible violación al artículo 6 del Convenio Europeo, es la habitual cercanía de los jueces administrativos con el poder ejecutivo. Asimismo, se ha cuestionado esa especie de "doble militancia" del principal órgano de justicia administrativa de muchos países europeos, esto es, el Consejo de

${ }^{34}$ Véase: Mengozzi, Marta, Giusto processo e processo amministrativo. Profili costituzionali (Milano, Giuffrè, 2009), p. 114. 
Estado, que emulando el modelo francés, existe también en Italia, Bélgica, Holanda y Luxemburgo ${ }^{35}$.

En Italia, como en la mayoría de estos países, el Consejo de Estado asume funciones jurisdiccionales y funciones consultivas en materias jurídico administrativas que sirven, obviamente, a la administración del Estado. Esa "doble militancia" está prevista en la propia Constitución italiana, por lo que se salvaría su constitucionalidad, pero se ha dicho que no es del todo claro que pueda considerarse válida al tenor de lo prescrito en el referido artículo 6.1 del Convenio Europeo ${ }^{36}$.

Las veces en que se ha cuestionado este problema del Consejo de Estado europeo referido a su "doble militancia", el TEDH ha manifestado que no corresponde tratar el problema desde una perspectiva general, sino que debe darse aplicación al artículo 6 del Convenio Europeo con referencia exclusiva al caso concreto sometido cada vez a su examen. Se afirma también, para excluir una posible violación al referido artículo 6 , que estén previstos los mecanismos que permitan garantizar la diversidad de personas físicas a las que es confiada la decisión sobre el mismo acto en los diversos cuerpos colegiados de este órgano ${ }^{37}$. Esta fue la primera posición delineada por el TEDH en sentencia de fecha 28 de septiembre de 1995 en el caso "Procola contra Luxemburgo".

Como las veces en que el TEDH se ha pronunciado sobre la conformidad o no al artículo 6,1 del Convenio Europeo de determinados órganos judiciales, lo ha realizado atendiendo el caso concreto que comprende un análisis del thema decidendi y de las partes de esa causa, en general se ha llevado el juicio de ilegitimidad a cuestiones que tienen que ver más con aspectos de imparcialidad que con independencia de los jueces. Sin embargo, esta jurisprudencia no ha terminado de asentarse y desde luego no es compartida por toda el TEDH, toda vez que existen jueces disidentes de dicha tribunal que consideran que en general y en abstracto, y no necesariamente atendido el caso concreto, no es legítima la traslapación de funciones jurisdiccionales y de gobierno en cabeza de un mismo órgano, por lo que postulan una separación clara entre ellas ${ }^{38}$. Estos jueces disidentes postularían en este caso problemas de falta de independencia de tales órganos.

${ }^{35}$ Sin embargo, en muchos de estos casos el TEDH no ha considerado que se trate de un problema que afecta a la independencia de esos órganos, sino que lo considera como un problema de falta de imparcialidad objetiva. Véase: Pedraz, Ernesto, cit. (n. 15), p. 215.

${ }^{36}$ Véase: MengozZi, Marta, cit. (n. 34), p. 162.

${ }^{37}$ Ibíd., p. 163.

${ }^{38}$ Ibíd., p. 164. 
La nominación de los jueces administrativos directamente por el ejecutivo es otro aspecto problemático desde el punto de vista del derecho de las personas a contar con jueces independientes. Sin embargo, en países como Italia, la Corte Constitucional no ha considerado contrario a la Constitución esta estrecha vinculación entre jurisdicción y ejecutivo. Esta orientación de la Corte Constitucional italiana ha sido criticada por un sector de la doctrina $^{39}$, toda vez que aparece evidente que la atribución del poder de elección para un determinado oficio a algún órgano o poder del Estado, puede crear entre éstos y aquellos que vienen designados ligámenes que pueden traducirse en una pérdida de independencia ${ }^{40}$.

A nivel americano, la Corte Interamericana de Derecho Humanos (en adelante $\mathrm{CIDH}$ ) ha señalado que la falta de independencia judicial, que conlleva la falta de imparcialidad, constituye una violación del artículo $8 \mathrm{CADH}$. así como una evidente carencia de igualdad para uno de los litigantes. Agrega que la independencia de la judicatura, como órgano, es fundamento esencial de la justicia que debe impartir el Estado, así como la independencia personal de los jueces es indispensable para asegurar su imparcialidad y hacer posible que puedan ejercer sus funciones con autonomía y sin presiones y ambas -independencia de la judicatura e independencia de los jueces- garantizan el derecho a un debido proceso de todas las personas sometidas a juicio, cualquiera sea la naturaleza de ésta ${ }^{41}$.

Los casos en que la CIDH ha dispuesto que determinados tribunales de países signatarios de la $\mathrm{CADH}$ atentan contra el derecho a un tribunal independiente, son aquellos en que se cuestiona la composición de esos tribunales, como ocurre con los militares. La CIDH considera que al haber tribunales militares que juzgan a civiles, con una composición por parte de funcionarios de las fuerzas armadas en servicio activo y bajo las órdenes del mando militar superior, vulnera ello el derecho a un tribunal competente, independiente e imparcial ${ }^{42}$.

${ }^{39}$ Marta Mengozzi cita los trabajos de autores como Mortati, Chieppa y Orsi Battaglini, entre otros. Cfr. Mengozzi, Marta, cit. (n. 34), p. 170.

${ }^{40}$ Véase: ZANON, Nicoló - BIONDI, Francesca, Il sistema costituzionale della magistratura (Bolonia, Zanichelli, 2006), p. 106

${ }^{41}$ Véase: Abreu, Alirio, Independencia judicial (jurisprudencia de la Corte Interamericana de Derechos Humanos), en Anuario de Derecho Constitucional Latinoamericano 13 (2007), p. 643.

${ }^{42}$ Véanse las sentencias "Castillo Petruzzi y otros contra Perú", de fecha 30 de mayo de 1999; "Durand y Ugarte contra Perú", de fecha 16 de agosto de 2000; "Palamara Iribarne contra Chil", de fecha 25 de noviembre de 2005. 


\section{SITUACIONES QUE PUEDEN CONSTITUIR UNA VULNERACIÓN DEL DERECHO A UN TRIBUNAL INDEPENDIENTE E IMPARCIAL EN EL DERECHO CHILENO}

\section{Situaciones referidas a la imparcialidad de los jueces en la justicia civil chilena.}

La única discusión relativa a la falta de imparcialidad de los jueces civiles chilenos que ha existido a un nivel exclusivamente doctrinal es la referida a si el poder que tienen por ley los jueces civiles para participar proponiendo o decretando pruebas de oficio afecta o no a su deber de imparcialidad y por tanto al derecho fundamental de los justiciables ${ }^{43}$. Tal facultad existe reconocida a nivel de jueces civiles como "medidas para mejor resolver" (artículo 159 CPC.) y como pruebas de oficio respecto de los jueces de familia (artículos 29 inciso final, 53, 61 No 8) y 64 de la Ley de Tribunales de Familia) y del trabajo (artículos 429, 453 № 9, 454 No 4 inciso final y 454 No 6 del Código del Trabajo).

Sobre este aspecto me he referido ya en otras oportunidades ${ }^{44}$, por lo que sólo agregaré ahora algunas breves consideraciones nuevas sobre el tema.

En primer lugar quiero recalcar que si la imparcialidad consiste, desde una perspectiva estrictamente subjetiva, en una equidistancia de los jueces respecto de las partes o un desinterés en relación con el objeto litigioso, por lo que los jueces sólo deben fallar según lo que prescriba la ley sin tomar en consideración otros intereses, es difícil comprender cómo esta doctrina llega a la conclusión que el juez que de oficio decreta pruebas en el proceso se torna parcial puesto que ese juez no tiene cómo saber a priori si el resultado de la prueba beneficiará a una u otra parte ${ }^{45}$. Un juez que participa del probatorio proponiendo o decretando pruebas no

${ }^{43}$ Sobre este aspecto, véanse: BотTO, Hugo, Inconstitucionalidad de las medidas para mejor resolver (Santiago de Chile, Editorial Fallos del Mes, 2001) p. 90 ss.; PALOMo, Diego, Proceso civil oral: ¿Qué modelo de juez requiere? en Revista de Derecho, Universidad Austral de Chile 18 (julio 2005) 1, p. 188.

${ }^{44}$ Véanse: Bordalí, Andrés, El debido proceso civil, en Ferrada, Juan Carlos (coordinador), La constitucionalización del Derecho chileno (Santiago, Universidad Austral de Chile, Editorial Jurídica de Chile, 2003), pp. 267 ss.; y DE LA Oliva, Andrés - Palomo, Diego (coordinadores), Los poderes del juez civil en Proceso civil. Hacia una nueva justicia civil (Santiago, Editorial Jurídica de Chile, 2007), pp. 179 ss.

${ }^{45}$ Sobre este aspecto, véase: PICÓ I JunOY, Joan, La iniciativa probatoria del juez penal y el principio acusatorio, en Romero SEGUel, Alejandro (editor), Estudios de derecho en homenaje a Raúl Tavolari Oliveros (Santiago de Chile, Universidad de los Andes - LexisNexis, 2007), p. 353. Para un análisis en el Derecho chileno: HunTeR Iván, Las potestades probatorias del juez de familia (Santiago de Chile, Universidad Austral de Chile - Legal Publishing, 2008), p. 71. 
se pone del lado de ninguna de las partes del proceso ni toma interés en el objeto litigioso. Cosa distinta es que del resultado de la prueba se vea beneficiado el demandante o el demandado, pero ello no obedece a la parcialidad del juez sino al poder intrínseco del medio probatorio para descubrir la verdad.

La doctrina crítica de los poderes probatorios oficiosos en poder del juez acostumbra a hacer una suerte de comunión entre pasividad del juez en materia probatoria, proceso de tipo adversarial y libertad y garantías para los justiciables, por lo que uno puede deducir a contrario que un juez con poderes probatorios oficiosos se asocia a proceso inquisitivo y con inexistencia de libertades y garantías para los justiciables ${ }^{46}$.

En relación a este punto de vista, señalaré que es evidente que un sistema procesal civil que dispusiera que el juez sea el único que ha de probar en el juicio impidiéndose a las partes ejercer su derecho a probar, es un sistema que afecta radicalmente el derecho de defensa de las partes. En este sentido es claro que ese proceso civil se mostraría en ese aspecto como inquisitivo, antilibertario y contrario a las exigencias de un debido proceso. Pero la realidad de la mayoría de los países occidentales, tanto del civil como del "common law", muestra que los poderes probatorios del juez son reconocidos conjuntamente con el derecho de las partes a probar sus alegaciones o bien con un carácter residual o complementario.

Es ésta la evolución que ha experimentado el proceso civil de tipo adversarial en el mundo contemporáneo, que se ha dado cuenta que un "adversary system" puro que entrega a las partes el dominio exclusivo de la conducción del proceso y la aportación de las pruebas, puede comportar en algunos casos un retardo en los tiempos procesales; un aumento en los costos económicos y sociales de la litigación; un incentivo para el desarrollo de estrategias y tácticas procesales de los abogados; una profundización de las desigualdades de las partes litigantes y, quizá lo peor de todo, un alejamiento de la necesaria justicia material de la decisión final ${ }^{47}$, en el entendido que el contradictorio entre partes, o más en general el debido proceso, es condición necesaria para la justicia de la decisión final pero no es causa suficiente ${ }^{48}$.

Nos encontramos de este modo tanto en Chile como en la mayoría de

${ }^{46}$ Por todos: Alvarado, Adolfo, Imparzialita del giudice e giusto processo, en CIPRIANI, Franco (coordinador), Stato di diritto e garanzie processuali. Atti delle II giornate internazionali di diritto processuale civile (Napoli, Edizioni Scientifiche Italiane, 2008), pp. 153 ss.

${ }^{47}$ Comoglio, Luigi Paolo, cit. (n. 16), p. 350.

${ }^{48}$ Taruffo, Michele, ¿Verdad negociada?, en Revista de Derecho Universidad Austral de Chile 21 (julio 2008) 1, p. 135. 
los países de cultura occidental frente a un proceso civil de tipo adversarial de tipo atenuado o mixto. No corresponde hablar por lo tanto de un proceso de tipo inquisitivo toda vez que el proceso se inicia sólo a requerimiento de parte interesada y ante un juez independiente del poder político de turno; las partes tienen total reconocimiento del derecho a contradecir y a defenderse en juicio, incluido desde luego el derecho a probar; el juez debe fundamentar fáctica y jurídicamente su sentencia; se puede recurrir ante un tribunal superior de la sentencia, etc. Por mucho que a este juez de este modelo adversarial atenuado o mixto se le confieran poderes probatorios ex officio, jamás podría ser considerado un juez inquisitivo y antilibertario. Quien así lo afirme podrá llenarse de aplausos ante una galería sedienta de emociones y pasiones frente al frío y a veces aburrido ambiente del procedimiento judicial, pero es poco prolijo en su análisis.

Esta doctrina que acusa violación del derecho a un juez imparcial cuando al juez civil se lo hace participar en la aportación de pruebas basa su argumentación en que habría una exigencia de regular el procedimiento civil de acuerdo a los cánones de un proceso adversarial o dispositivo. Parece entenderse de esta crítica que éste sería el único modelo de proceso civil coherente con los derechos que reconoce la Constitución Politica de la República.

Más allá de rechazar de plano una idea tal como que la Constitución impone determinado modelo procesal civil ${ }^{49}$, destacaré que todo intento de conservar un proceso civil de tipo adversarial en su modelo puro es hoy en día imposible. El origen del modelo adversarial está en el ordo iudiciaris que existía en el mundo jurídico europeo anterior al siglo XIII, el que es caracterizado por su naturaleza extraestatal ${ }^{50}$; no positivo; no dependiente de una voluntad reguladora externa; que presupone la igualdad entre gobernantes y gobernados; donde la función del juez consiste en lo central en individualizar una entre dos hipótesis argumentativas que resulta ser la más persuasiva y por lo tanto cercana a una verdad probable ${ }^{51}$.

\footnotetext{
${ }^{49}$ La Constitución no impone ni designa modelos procesales de ningún tipo. Lo único que hace es establecer ciertos límites al legislador para la regulación de los procesos judiciales. Esos límites están determinados por las exigencias del debido proceso como derecho de los justiciables. En este sentido no puede decirse que un modelo adversarial o dispositivo de proceso civil sea una exigencia constitucional.

${ }^{50}$ Su carácter extraestatal y por consiguiente "natural" significaba que ni siquiera el papa habría podido prescindir y restarse o modificar del ordo iudiciaris. La intervención del Príncipe o de cualquiera otra voluntad externa, habría representado una perversio ordinis que se habría traducido en una acción odiosa, similar a alterar la moneda. Véase: PiCARDI, Nicola, La giurisdizione all alba del terzo milenio (Milano, Giuffrè, 2007), pp. 234-235.

${ }^{51}$ Véase: CHIzZINI, Augusto, Brevi spunti in tema di oralità e dimensione retorica
} 
Ese tipo de proceso era el reflejo de un determinado sistema político y social, que a juicio de Chizzini ${ }^{52}$ comportaba un eficaz instrumento de consolidación del Derecho dentro de una estructura social caracterizada por la descentralización de los poderes. Los individuos, en este momento histórico, no tienen derechos reconocidos por ningún poder político o social existente, sino que dichos derechos existen por obra y gracia de la retórica y la ética ${ }^{53}$.

Es evidente que la estatalización progresiva que se registra en el mundo europeo desde aproximadamente el siglo XIII en adelante, iba a traer como consecuencia necesaria el fin del proceso de tipo adversarial. Desde luego aparece algo que hasta ese momento no existía: la jurisdicción como expresión de un poder político central. Irrumpe así la figura de un juez burócrata, es decir, funcionario del Estado el que luego deberá dar aplicación al derecho del Estado. Y con la aparición del juez burócrata se acaba el orden simétrico que caracterizaba al mundo extraestatal. El juez viene ahora considerado suprapartes. Viene por lo demás reemplazada la fuerza de la retórica y de la dialéctica por una racionalidad subjetiva, formal y calculadora ${ }^{54}$.

A diferencia del mundo antiguo donde la verdad no existe antes y fuera del proceso ${ }^{55}$, en el proceso del Estado moderno la verdad extraprocesal tiene importancia, por lo que la primacía de la retórica consecuencialmente decae y como método que se tenía para el establecimiento de la verdad decae a un mero ornatum del discurso. Pero hay más, el contradictorio viene a veces considerado como una obstrucción en la búsqueda de la verdad para el fin de tutelar los derechos de las personas ${ }^{56}$.

La aparición del juez como expresión del poder estatal, como asimismo la aparición de un Derecho estatal, traen como necesaria consecuencia que el proceso ya no sea cuestión que interesa sólo a los justiciables sino también al juez cual representante del poder del Estado. Una vez que ese juez estatal pasa a formar parte de un Estado de Derecho, hay que señalar que el objeto litigioso claramente interesa sólo y exclusivamente a las partes, pero el juez aparece interesado en el proceso. Ese interés dice relación con

nella genesi del processo civile, en Manzini, Maurizio - Puppo, Federico (a cura di), Audiatur et altera pars. Il contradittorio fra principio e regola, (Milano, Giuffrè, 2008), p. 101.

${ }^{52}$ Cfr. Chizzini, Augusto, cit. (n. 51), p. 104.

${ }^{53}$ Véase: Chizzini, Augusto, cit. (n. 51), pp. 104-105.

${ }^{54}$ Véase: PiCARDi, Nicola, cit. (n. 50), p. 241.

${ }^{55}$ Véase: Puppo, Federico, La forma retorica del contradittorio en MANZINI, Maurizio - Puppo, Federico (a cura di), Audiatur et altera pars, cit. (n. 51), p. 32.

${ }^{56}$ Ibíd., p. 34. 
el proceso mismo y con el resultado del proceso. En relación al proceso, al juez le interesa que se desarrolle de la forma prevista por la ley y de la manera más eficiente posible. En relación al resultado del proceso, al juez le interesa que la sentencia que dictará sirva para dar vida al Derecho que han creado los otros órganos estatales. Y para dar vida al Derecho no hay otra posibilidad que acercarse con la prueba lo más que se pueda a la verdad extraprocesal.

$\mathrm{Ni}$ aun los países anglosajones que se consideran los mejores herederos del "adversary system" del mundo antiguo consideran que el proceso pueda ser cuestión que atañe sólo a las partes. Desde luego los jueces del "common law" no sólo tienen poderes de dirección formal del proceso en la lógica del "Managment of the cause" ${ }^{\text {", }}$ sino que también tienen poderes probatorios oficiosos ${ }^{58}$.

Concuerdo con la apreciación general sobre esta materia que formula Comoglio ${ }^{59}$, en el sentido que el juez debe valerse de sus poderes de iniciativa probatoria oficiosa de un modo imparcial, en el sólo interés objetivo de la búsqueda y la determinación de la verdad histórica de los hechos controvertidos, a los fines de remover objetivas y concretas dificultades o incertezas probatorias no superables para las partes, que de otro modo perjudicarían tal determinación.

Cuando se expresa que es necesario reconocer poderes probatorios a los jueces no se intenta negar el poder técnico y ético ${ }^{60}$ que tiene el contradictorio entre partes como herramienta que permite obtener información $y$ acercarse a la verdad ${ }^{61}$. De lo que se trata es que el juez pueda colaborar en un diálogo más amplio para la comprobación de los hechos.

Concluyo en esta parte señalando que un modelo de proceso civil de tipo adversarial atenuado que respete el debido proceso de los justiciables, puede conferir poderes probatorios a los jueces sin que ello afecte per se su imparcialidad. La experiencia muestra que en la medida en que las partes utilicen el proceso sin incurrir en mala fe y estén representados por adecuados técnicos del derecho, los jueces no necesitan usar sus poderes

${ }^{57}$ Véase: Comoglio, Luigi Paolo, cit. (n. 16), p. 350.

${ }^{58}$ Véase: TARUfFo, Michele, Investigación judicial y producción de prueba por las partes en Revista de Derecho Universidad Austral de Chile 15 (diciembre 2003), p. 211.

${ }^{59}$ Cfr. Comoglio, Luigi Paolo, cit. (n.16), p. 353.

${ }^{60} \mathrm{Se}$ habla a veces que más que corresponder a una regla procesal, el contradictorio entre partes asume un rol de principio del ordenamiento jurídico. Véase: MANZIN, Maurizio, Del contradittorio como principio e come metodo en MANZINI, Maurizio - Puppo, Federico (a cura di), Audiatur et altera pars, cit. (n. 51), p. 13.

${ }^{61}$ Véase: PiCARdi, Nicola, cit. (n. 50), n. 235. 
probatorios. Eso es así tanto en países del "civil law" como del "common law".

Situaciones referidas a la imparcialidad de los jueces en la justicia penal chilena.

Con la modificación de la justicia penal en el año 2000, la verdad es que de una manera general no se presentan hoy en día situaciones que pudieran poner en entredicho el derecho de los justiciables a un tribunal independiente e imparcial. Habiéndose separado claramente las funciones de investigación, acusación y juzgamiento en órganos diferentes, por una parte, y previendo la ley procesal penal que, por regla general, los tribunales que otorgan medidas cautelares personales (juzgado de garantía) y los que luego juzgan (tribunal de juicio oral en lo penal) sean diferentes, no se presentan problemas de falta de independencia o imparcialidad.

Para quienes sostengan que un juez que dispone medios probatorios pierde su imparcialidad, el Código Procesal Penal les da en el gusto, pues salvo el poder de los jueces para pedir a los testigos que aclaren sus dichos (artículo 329 inciso 40 CPP.) y la denominada "prueba sobre prueba" (artículo 336 inciso $2^{\circ} \mathrm{CPP}$.), dichos jueces no tienen poderes probatorios oficiosos. En esta parte el legislador chileno siguió la senda de un modelo de proceso penal adversarial o acusatorio puro, donde el poder de probar sólo corresponde a las partes.

No es este el momento de discutir si ha hecho bien o no el legislador chileno en esta materia. Sólo destacaré por ahora que al existir un organismo estatal autónomo (Ministerio Público) que se rige por el principio de objetividad (artículo 3 Ley No 19.640 sobre el Ministerio Público) ${ }^{62}$, órgano al que le corresponde en exclusiva dirigir la investigación y en su caso acusar dando lugar al juicio oral, puede entenderse que no se permita al tribunal de disponer medios probatorios de oficio. La función de justicia en el sentido de hacer aplicar la ley ya estaría asignado en parte al órgano persecutor estatal. Por otra parte, un respeto irrestricto del principio de presunción de inocencia también parecería aconsejar no darle estos poderes probatorios oficiosos al tribunal, pues una actuación del tribunal podría perjudicar este halo protector del que están provistos todos los imputados por delito.

Sin embargo, cuando digo que el legislador chileno siguió en esta materia un modelo adversarial o acusatorio bastante puro, como existe

${ }^{62}$ Disposición que prevé que: "en el ejercicio de su función, los fiscales del Ministerio Público adecuarán sus actos a un criterio objetivo, velando únicamente por la correcta aplicación de la ley [...]". 
en la justicia penal anglosajona contemporánea, no se debe ocultar que este no ha sido el camino de las democracias europeas, pues la inmensa mayoría de ellas contemplan poderes probatorios oficiosos en manos de sus jueces penales. Eso es así en Alemania, España, Francia, Holanda, Italia y Portugal, según la reseña que formula Picó i Junoy ${ }^{63}$.

Por otra parte, y como destaca este mismo autor, la situación de absoluta pasividad en materia de prueba de los jueces penales anglosajones quizá no se deba a consideraciones constitucionales, ideológicas o de coherencia con un modelo de juez, sino a la función que cumple este juez penal, quien sólo es dueño del proceso y no de la decisión final que pertenece al jurado. La nítida disociación ${ }^{64}$ que existe entre juez y jurado (o entre cuestiones de Derecho y de hecho si se quiere) en los países anglosajones, podría ser el motivo de la pasividad de los jueces penales anglosajones ${ }^{65}$. Al no existir jurado en Chile, se debe advertir entonces que la opción legislativa chilena en orden a no conceder poderes probatorios oficiosos a los jueces penales no estaría "anclada" en un modelo ideológico y constitucional suficientemente claro y firme. Existe aquí una tarea pendiente de analizar y discutir para la doctrina chilena.

Sin perjuicio de que por regla general, como se ha dicho, no existan situaciones en el Código Procesal Penal que podrían dar lugar a situaciones de afectación de la independencia e imparcialidad de los jueces, hay algunas situaciones que de una manera más marginal podrían comprometer la imparcialidad judicial.

Es el caso, en primer lugar, del tribunal oral en lo penal que en la o las audiencias de juicio oral decreta la prisión preventiva del acusado, según lo permite el artículo $142 \mathrm{CPP}$. La hipótesis más previsible a este respecto es el caso del acusado que ha estado sin medidas cautelares personales a su respecto y que atendida la sospecha del tribunal de juicio oral que el proceso podrá durar varios días, decrete en la primera audiencia de juicio la prisión preventiva o alguna del artículo 155 del CPP. La valoración que hace el tribunal oral para determinar por ejemplo, en una medida cautelar de prisión preventiva, la existencia del delito y que el acusado ha tenido

${ }^{63}$ Cfr. Picó i Junoy, Joan, cit. (n. 45), pp. 339 ss.

${ }^{64}$ Téngase presente que la modalidad de juicio por jurado de algunos países europeos como Alemania, Francia e Italia difiere de la anglosajona, pues en estos países existe el jurado tipo escabinado o mixto, órgano compuesto de jueces togados y ciudadanos, los que conocen en conjunto las cuestiones de hecho y de derecho. Sobre este aspecto: Pedraz, Ernesto, Participación popular en la justicia penal, en Revista de Derecho Universidad Austral de Chile, número especial: La reforma procesal penal (agosto 1999), pp. 79 ss.

${ }^{65}$ Véase: Picó I Junoy, Joan, cit. (n. 45), p. 352. 
participación en dicho delito como autor, cómplice o encubridor, podría llevarlo en virtud de la denominada fuerza de la prevención a mantener esa valoración al momento de dictar la sentencia. De hecho esta situación está expresamente vedada por los artículos 34 y 35 del Código de Procedimiento Penal italiano.

Se comportaría así esta valoración cautelar como un prejuicio que le restaría serenidad y claridad al tribunal para enjuiciar la existencia del delito y participación del acusado en él. En tal situación, el acusado y luego condenado podría intentar dos cosas, conjunta o alternativamente. Un recurso de nulidad ante la Corte Suprema invocando el derecho a un tribunal independiente e imparcial según lo prescrito por el artículo 373 a) CPP., o bien un recurso de inaplicabilidad ante el Tribunal Constitucional contra el artículo $142 \mathrm{CPP}$. antes que se dicte la sentencia definitiva en esa causa. Todo ello sin perjuicio de considerar en un plano de lege ferenda la posibilidad de incorporar en este caso un instrumento procesal en las manos del acusado que duda de la imparcialidad del juez para recusarlo por motivo serio y grave.

Luego está la situación de la resolución de un juez penal sobre la solicitud de una medida cautelar personal de la que se puede apelar ante la Corte de Apelaciones respectiva (artículo 149 CPP.). Esa Corte al conocer del recurso hará valoraciones sobre la existencia del delito y sobre la culpabilidad del imputado o acusado. Luego esa Corte podrá volver a conocer de estos asuntos como tribunal de nulidad. Podría darse en estos casos una nueva situación de fuerza de la prevención que podría hacerle perder al tribunal su imparcialidad.

El TEDH en general ha rechazado las acusaciones deducidas por los ciudadanos europeos por situaciones como las expuestas acá ${ }^{66}$. Por el contrario, la Corte Constitucional italiana, como hemos visto, aparece más severa en esta materia que el TEDH. La Corte italiana destaca que la propensión del juez a confirmar una decisión suya precedente es muy fuerte de modo tal que es capaz de incidir sobre la garantía de un juicio que sea el fruto genuino y exclusivo de los elementos de valoración y de prueba asumidos en el proceso y del despliegue de la defensa de las partes ${ }^{67}$.

Haría bien el legislador chileno si dispusiera que el tribunal que determina una medida cautelar personal luego no puede resolver sobre el mérito de la causa. Asimismo, la Corte de Apelaciones que ha debido conocer

${ }^{66}$ Véase: sentencias TEDH "Hauschildt con Dinamarca" de 24 de mayo de 1989; "Oberschlink con Austria" de fecha 23 de mayo de 1991.

${ }^{67}$ Véase: Roiati, Alessandro, cit. (n. 31), p. 9. 
de una apelación de una medida cautelar personal no debería conocer del recurso de nulidad contra la sentencia definitiva.

3. Situaciones referidas a la independencia e imparcialidad de los jueces en la justicia administrativa chilena.

Sobre la situación de la independencia e imparcialidad en la justicia administrativa chilena ya me he referido en varios trabajos previos ${ }^{68}$. Se puede resumir mi punto de vista en esta materia señalando que cada vez que se considera que cuando la Administración resuelve un asunto o determina derechos lo hace como órgano que ejerce jurisdicción o como tribunal especial, se vulneraría el derecho de esas personas a contar con un tribunal independiente e imparcial.

Como sabemos nuestra doctrina y jurisprudencia tienen una concepción bastante amplia de lo que debe entenderse por jurisdicción, lo que ha llevado a entender que cuando la administración del Estado decide o determina un derecho de un particular actúa como jurisdicción o como un tribunal de justicia especial situado fuera del Poder judicial. Se presenta acá un problema que puede ser considerado de falta de independencia como de falta de imparcialidad objetiva.

La cuestión ha sido analizada a los ojos del TEDH como un problema de si es legítimo que estos órganos administrativos tengan una especie de "doble militancia", es decir, que desarrollen conjuntamente funciones jurisdiccionales como administrativas. La solución que ha prospectado el TEDH para no declarar la ilegitimidad de tal regulación, que es muy común como veíamos páginas atrás en el Consejo de Estado de tipo europeo, pasaría por garantizar la diversidad de personas físicas a las que es confiada la decisión sobre el mismo acto en los diversos cuerpos del órgano ${ }^{69}$. Esta doctrina podría haberse aplicado a los casos en que el Servicio de Impuestos

${ }^{68}$ Véase: Bordalí, Andrés, Principios de una nueva justicia administrativa en Chile, en Ferrada, Juan Carlos (coordinador), La justicia administrativa (Santiago de Chile, Universidad Austral de Chile - LexisNexis, 2005), pp. 341 ss.; La administración pública ante los tribunales de justicia chilenos, en Revista Chilena de Derecho 33 (enero-abril 2006) 1, pp. 17 ss.; La independencia del poder judicial en el sistema constitucional chileno, en Romero Seguel, Alejandro (editor), Estudios de Derecho en homenaje a Raúl Tavolari Oliveros (Santiago de Chile, Universidad de los Andes - LexisNexis, 2007), pp. 509 ss.; La doctrina de la separación de poderes y el Poder Judicial chileno, en Revista de Derecho Pontificia Universidad Católica de Valparaíso 30 (2008, semestre I), pp. 185 ss.; Organización judicial en el Derecho Chileno: Un poder fragmentado, en Revista Chilena de Derecho 36 (mayo-agosto 2009) 2, pp. 215 ss.

${ }^{69}$ Véase: Mengozzi, Marta, cit. (n. 34), p. 163. Esta fue la primera posición delineada por el TEDH en sentencia de fecha 28 de septiembre de 1995 en el caso "Procola contra Luxemburgo". 
Internos liquida un impuesto y luego conoce de la reclamación contra esa liquidación. Siguiendo la jurisprudencia del TEDH no habría problema de legitimidad constitucional en ello si existe separación de personas físicas entre quien liquida el impuesto y quien conoce de la reclamación.

Sin embargo, el problema se presenta muchas veces en Chile cuando ya no hay "doble militancia", sino cuando la actividad administrativa se la hace pasar derechamente por jurisdiccional, como es la tesis de Enrique Evans en nuestro país que ha recibido un fuerte respaldo doctrinal y jurisprudencial. Sostiene este autor que cuando la Administración impone sanciones o, por ejemplo, priva de la personalidad jurídica a una organización, ejerce en estos casos jurisdicción y el reclamo que se haga ante la justicia ordinaria no es más que la continuación de ese proceso jurisdiccional ante un tribunal superior $^{70}$. Hay aquí a mi entender un problema grave de afectación del derecho fundamental a un tribunal independiente e imparcial y desde luego del derecho de acceso a la justicia, porque la ley le estaría privando a los justiciables del derecho a acudir ante una verdadera jurisdicción en primera instancia para reclamar de los actos de la Administración (artículo $19 \mathrm{No}^{\circ} 3$ inciso $1^{\mathrm{o}}$ y 38 inciso $2^{\mathrm{a}}$ C.Pol.).

Se trataría en estos casos de "jueces administrativos" que son nominados directamente por el ejecutivo, lo que no se ajustaría con las exigencias de un debido proceso, toda vez que aparece evidente que la atribución del poder de elección para un determinado oficio a algún órgano o poder del Estado, puede crear entre éstos y aquellos que vienen designados ligámenes que pueden traducirse en una pérdida de independencia ${ }^{71}$. Lo mismo viene dado por las reglas que determinan la amovilidad de estos funcionarios administrativos que no se ajustan a las exigencias que reclama un estatuto de un juez que garantice independencia e imparcialidad.

Uno de los aspectos más relevantes de la justicia es que los ciudadanos puedan confiar en las decisiones de los jueces. De ahí que sean relevantes los aspectos organizativos y la configuración de los tribunales de justicia. Puede ser que un funcionario administrativo que está sujeto a las instrucciones del poder ejecutivo central sea capaz de aplicar el Derecho imparcialmente en ese caso concreto, sin que se deje influenciar o presionar por sus directivos, pero en estas materias importan las apariencias de independencia e imparcialidad para legitimar de mejor modo el actuar del Estado. El TEDH ha realizado este tipo de apreciaciones en sus sentencias "Delcourt contra Bélgica", de fecha 17 de enero de 1970 y "Piersack contra Bélgica", de fecha 1 de octubre de 1982.

\footnotetext{
${ }^{70}$ Evans, Enrique, cit. (n. 1), p. 144.

${ }^{71}$ Véase: Zanon, Nicoló - Biondi, Francesca, cit. (n. 40), p. 106.
} 
De un modo tajante me permito señalar que toda vez que la Administración Pública chilena actúa como tribunal de justicia constituye ello una violación flagrante del derecho fundamental de las personas de acceso a la justicia y del derecho a un tribunal independiente e imparcial.

\section{Situaciones referidas a la independencia e imparcialidad de los jueces} en la justicia militar chilena.

Existe en nuestro país un consenso bastante amplio referido a que la justicia militar chilena en tiempos de paz no respeta las exigencias de un debido proceso. El Código de Justicia Militar vigente juzga tanto a militares como a civiles, lo que supone un forzamiento y extralimitación de la competencia de estos tribunales. En materia de juzgamiento de conductas penales por estos tribunales no hay respeto adecuado del derecho de defensa y a un juicio oral y público, amén de no contarse con una justicia realmente independiente e imparcial ${ }^{72}$.

En la sentencia "Palamara Iribarne contra Chile", de fecha 22 de noviembre de 2005, la CIDH ha cuestionado la composición de los tribunales militares que juzgan a civiles, toda vez que estos tribunales se encuentran integrados por miembros de las fuerzas armadas en servicio activo, lo que los inhabilita para rendir un examen independiente e imparcial.

Sin embargo, la posición de la CIDH es criticable por inconsistente, toda vez que es jurisprudencia ya asentada de esta Corte que la función judicial recae eminentemente sobre el Poder judicial, pero ello no impide que otros órganos públicos también desarrollen tal función judicial, como ocurre con los órganos administrativos y legislativos. Todo órgano público puede determinar los derechos de las personas, pero siempre deberá atenerse a las garantías de un debido proceso ${ }^{73}$.

Es criticable esta posición de la CIDH toda vez que si la función judicial puede ser desarrollada por los órganos políticos, ya sea del ejecutivo o legislativo, no se ve cómo se puede garantizar el debido proceso en estos casos si por definición falta el requisito de la independencia externa de esas autoridades públicas. La propia CIDH ha sostenido que la independencia del juez y de los tribunales es uno de "los fundamentos esenciales del

${ }^{72}$ Para una visión general de esa doctrina nacional crítica del enjuiciamiento militar chileno en tiempos de paz, remito al trabajo de Díaz, Regina, Reforma de la justicia militar chilena a la luz de las consideraciones del fallo Palamara: Sentencia Corte Interamericana de Derechos Humanos Palamara Iribarne vs Chile, 22 de noviembre de 2005, en Revista Chilena de Derecho 34 (abril 2007) 1, pp. 139 ss.

${ }^{73}$ Véase: entre otros casos, "Claude Reyes y otros contra Chile", sentencia de fecha 19 de septiembre de 2006. Existe comentario de mi autoría a este fallo en Revista de Derecho de la Universidad Austral de Chile 20 (Julio 2007) 1, pp. 289 ss. 


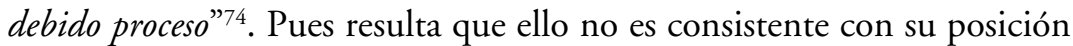
también amplia del concepto de jurisdicción, toda vez que siempre que una autoridad no judicial resuelva un asunto determinando los derechos de las personas, lo hará sin el requisito de la independencia que es exclusiva de los jueces.

No se comprende de esta manera el cuestionamiento de la falta de independencia que la CIDH hace de los tribunales militares, si esta misma corte permite por ejemplo que la administración del Estado resuelva asuntos donde los jueces administrativos forman parte de uno de los poderes políticos activos del Estado y donde nunca podrá predicarse independencia, pues el funcionario administrativo está sujeto a un control jerárquico superior y fallará sobre aspectos donde esa administración tiene interés. Para que la CIDH fuera coherente en esta materia, debería decir que se afecta el derecho a un tribunal independiente y, por lo tanto, el derecho a un debido proceso, siempre que quien ejerza la función judicial no sea un tribunal de justicia entendido en términos precisos y restrictivos. Así, sería atentatorio del artículo 8,1 CADH. si quien determina los derechos de las personas es un tribunal militar o la Administración del Estado.

Si la CIDH quiere mantenerse en la línea de que todo órgano que determina derechos es un tribunal de justicia, debería sostener consecutivamente que no se afectaría el derecho a un tribunal independiente si la determinación de tales derechos la realiza cualquier órgano del Estado, sea administración, órgano legislativo o las fuerzas armadas, con tal que se respeten las demás garantías del debido proceso (derecho de defensa, derecho a probar, derecho a los recursos, etc).

Pareciera que los problemas de la justicia militar chilena, siguiendo esta jurisprudencia de la CIDH, no pasaría tanto por un problema de falta de independencia, sino por una competencia que desborda los "cauces naturales" de este tipo de jurisdicción, al juzgar a civiles y no limitar su competencia a militares en servicio activo.

Al contrario de la posición de la $\mathrm{CIDH}$, sostengo que uno de los problemas de la justicia militar chilena apunta al hecho que quien juzga no es un tribunal independiente, toda vez que por tratarse de funcionarios de las fuerzas armadas en servicio activo y dada la organización jerárquica al interior de estas unidades, el juez que falla no puede sentirse vinculado sólo y nada más que a la ley. Sin independencia orgánica, a mi entender, no hay jurisdicción legítima, pero eso no vale sólo para los jueces militares sino también para la administración cuando hace de jurisdicción.

Lo que es evidente a estas alturas, es que la justicia militar tiene que

${ }^{74}$ Abreu, Alirio, cit. (n. 41), p. 640. 
modificarse y ajustarse a las garantías del debido proceso que suelen garantizar los procesos penales de tipo acusatorio. No se observan mayores voces críticas de esta necesidad, ni siquiera al interior de la justicia castrense.

5. Situaciones referidas a la imparcialidad de los jueces en la justicia constitucional chilena.

A los ministros del Tribunal Constitucional se les aplican algunas de las normas sobre implicancia del artículo 195 COT., en particular, las de los números 2, 4, 5, 6 y 7 de ese artículo. Así lo dispone el artículo 19 de la Ley orgánica del Tribunal Constitucional (en adelante LOCTC.) que además agrega una especial norma de implicancia para las competencias de los números 1 al 16 del artículo 93 C.Pol., cual es que el ministro haya emitido opinión con publicidad o dictamen sobre el asunto concreto actualmente sometido a conocimiento del Tribunal.

Hay aquí una especial consideración de la denominada fuerza de la prevención. Dada una opinión con publicidad o un dictamen sobre un asunto concreto, es de suponer que ese juez intentará mantener ese juicio en el nuevo proceso que tiene que conocer y fallar, por lo que ese juez no podrá juzgar con total serenidad. Se entiende de este modo que se configura una especial incompatibilidad que le hace perder la imparcialidad.

Esta cuestión se ha planteado últimamente en la causa rol No 740-2008 que recayó en el caso conocido como de la "Píldora del día después". En esta causa los ministros Raúl Bertelsen Repetto y Enrique Navarro Beltrán plantearon que en la causa caratulada "Centro Juvenil AGES con Instituto de Salud Pública", nulidad de Derecho público, incoada hace algunos años ante el $20^{\circ}$ Juzgado Civil de Santiago, firmaron, junto con otros profesores, un informe en Derecho que lleva por título "El derecho a la vida y su titularidad. Algunas consideraciones a propósito de la comercialización de la droga levonorgestrel 0.75”. El señor Bertelsen expresó que en lo personal no se consideraba incluido en la causal de inhabilitación en cuestión, pero lo sometió a decisión del Tribunal. Al contrario, el ministro Navarro sí se consideró inhabilitado por esta causal, y lo sometió de este modo a consideración del Tribunal.

En la misma oportunidad, el ministro señor Francisco Fernández Fredes planteó que a su juicio, los Ministros señores Bertelsen y Navarro se encuentran comprendidos en la hipótesis de implicancia indicada en el artículo 19, inciso primero, LOCTC. En atención a lo anterior promovió cuestión de implicancia de los aludidos ministros para entrar a conocer de esta causa.

El Tribunal Constitucional aceptó la implicancia para entrar a conocer de esta causa planteada por el ministro señor Enrique Navarro Beltrán, 
teniendo especialmente presente lo expuesto por él y lo dispuesto en el inciso $3^{\circ}$ del artículo 19 LOCTC. Rechazó, por el contrario, la implicancia del Ministro señor Raúl Bertelsen Repetto, por considerar que a su respecto no se encuentra configurada la causal de implicancia invocada.

La implicancia del ministro señor Enrique Navarro Beltrán fue acordada con el voto en contra de los ministros señores José Luis Cea Egaña, Mario Fernández Baeza y Marcelo Venegas Palacios, quienes estuvieron por rechazarla por estimar que no se cumplen a su respecto los requisitos de la causal prevista en el artículo 19, inciso $1^{\circ}$, LOCTC., pues el dictamen invocado fue emitido con a lo menos tres años de anterioridad al inicio de la presente causa y versa sobre un asunto concreto que dice relación con la nulidad de Derecho público de una autorización sanitaria, materia completamente distinta a la debatida en estos autos que consiste en la declaración de inconstitucionalidad de normas determinadas del Decreto supremo No 48, de 2007, del Ministerio de Salud, publicado en el Diario Oficial de 3 de febrero del presente año, que se impugnan por los requirentes.

Por su parte, el rechazo de la implicancia planteada por el ministro señor Raúl Bertelsen Repetto fue acordado con el voto en contra de los Ministros señores Hernán Vodanovic Schnake, Jorge Correa Sutil y Francisco Fernández Fredes, quienes estuvieron por acogerla por considerar que en el dictamen aludido se contienen opiniones sobre todos los problemas que deben resolverse en el requerimiento sujeto actualmente a la decisión del Tribunal.

La cuestión, como puede observarse, dividió la opinión del Tribunal Constitucional. $Y$ es comprensible que haya existido duda a este respecto, toda vez que es de común ocurrencia, por exigirlo así el Artículo 92 C.Pol., que los miembros del Tribunal Constitucional sean abogados de reconocida figuración pública, personeros políticos o profesores o investigadores universitarios o de centros de estudios. En este sentido, es de normal ocurrencia que los ministros del Tribunal Constitucional hayan dado una opinión o dictamen previo sobre el asunto que tienen que resolver, ya en un artículo científico, en un informe en Derecho, en una carta o columna de opinión de un periódico, etc.

La Constitución exige que los miembros del Tribunal Constitucional sean personas que gocen de la debida capacidad profesional y de prestigio o auctoritas, y eso generalmente involucrará para sus integrantes figuración en la vida profesional o pública lo que incluye, muchas veces, haber dado opiniones públicas sobre materias constitucionales. ¿Cómo conciliar entonces esta necesidad de contar con jueces constitucionales dotados de auctoritas con la causal de inhabilitación en cuestión?

El asunto no puede ser entendido en los mismos términos que lo 
dispuesto para la judicatura ordinaria en el artículo 195 No 8 COT., que establece como causa de implicancia el "haber el juez manifestado su dictamen sobre la cuestión pendiente con conocimiento de los antecedentes necesarios para pronunciar sentencia". Esta causal de implicancia supone que el juez ha pronunciado su opinión sobre una causa concreta que involucra a las mismas personas, el mismo objeto litigioso y la misma causa de pedir. Esta causal supone adelantar el juicio de la sentencia que afecta a un caso concreto en los términos expuestos.

Ante el Tribunal Constitucional sólo podría configurarse esta causal de inhabilidad cuando se deba juzgar de una manera similar a como lo hace la judicatura ordinaria, es decir, cuando se trata de un caso concreto referido a las mismas personas, mismo objeto litigioso y misma causa de pedir. Eso sólo podría darse respecto de algunas de las competencias atribuidas por el artículo 93 C.Pol. al Tribunal Constitucional. Esas causas son aquellas no referidas al control de constitucionalidad de preceptos jurídicos. Se trata de las competencias del Tribunal Constitucional para resolver sobre la inhabilidad de una persona para ser designada Ministro de Estado, permanecer en dicho cargo o desempeñar simultáneamente otras funciones, o sobre las inhabilidades de los parlamentarios y quizá la declaración de inconstitucionalidad de un movimiento o partido político, así como la determinación de la responsabilidad de las personas que participaron en los hechos que motivaron esa declaración de inconstitucionalidad. En todas estas competencias hay un caso concreto muy similar a como ocurre ante la judicatura civil o penal.

En el control de constitucionalidad de preceptos jurídicos, aun en el caso de la inaplicabilidad de las leyes, la jurisprudencia muestra que lo que siempre se termina por enjuiciar es un precepto legal de un modo abstracto, por mucho que la reforma constitucional del año 2005 y los mismos jueces constitucionales digan actualmente lo contrario ${ }^{75}$. En realidad, el caso concreto en la cuestión de inaplicabilidad es generalmente una excusa para declarar inconstitucional un precepto legal, aunque la Constitución prevea que dicha declaración tendrá efectos inter partes. Hay bastante de irrealidad en la afirmación de que la situación de las partes y del objeto debatido de la gestión judicial pendiente -el caso concreto- es relevante para determinar la declaración de inaplicabilidad del precepto legal que debe aplicarse en esa causa.

${ }^{75}$ Un análisis lo suficientemente crítico de cómo opera el control concreto de constitucionalidad ante el Tribunal Constitucional chileno puede verse en NúNEz, Manuel Antonio, El control de la igualdad en la aplicación de la ley como factor de expansión del control concreto de constitucionalidad de las leyes en Sentencias destacadas 2007 (Santiago de Chile, Libertad y Desarrollo, 2008), pp. 123 ss. 
Los jueces constitucionales cuando deben pronunciarse sobre la constitucionalidad o inconstitucionalidad de un precepto jurídico terminan por hacer una declaración general sobre el precepto, juicio que irremediablemente está sembrado de cuestiones ideológicas y políticas. La justicia constitucional es una justicia en que lo jurídico y lo político están absolutamente entrelazados.

Lo anterior viene a significar que la implicancia específica construida para los jueces constitucionales por el artículo 19 LOCTC., no se aviene con la propia naturaleza de la justicia constitucional. Ésta siempre supone un juicio político o ideológico, aunque limitado y moderado por exigencias jurídico constitucionales. Asimismo no se aviene con la necesidad de contar con adecuados jueces constitucionales, que son personas que generalmente expresan sus juicios políticos, ideológicos y jurídicos de manera previa a asumir en esta magistratura constitucional. Por lo demás, debe ser valorado positivamente que estas personas expresen sus juicios públicamente, toda vez que de conformidad con ellos los distintos poderes públicos (presidente de la República, Senado, Cámara de Diputados y Corte Suprema) podrán realizar la designación que corresponda de conformidad con el artículo 92 C.Pol.

La causal de implicancia analizada no permite comprender adecuadamente a la justicia constitucional y el rol de los jueces constitucionales que en estas materias se comportan de una manera completamente diferente a la jurisdicción civil y penal. Por estos motivos, haría bien el Tribunal Constitucional en dar una aplicación a esta causal de inhabilidad con un carácter muy restringido, en ningún caso cuando se trate de controlar la constitucionalidad de preceptos jurídicos.

Todo lo anterior no exonera al Tribunal Constitucional en la sentencia sobre la "píldora del día después" al haber declarado la inhabilidad para un ministro y no para el otro, siendo que estaban en la misma situación. No hizo bien este máximo tribunal al vulnerar de una manera tan flagrante el principio constitucional de igualdad ante la ley.

\section{CONCLUSIONES}

La Constitución Política de la República de Chile y los tratados internacionales sobre derechos humanos ratificados por Chile y vigentes, exigen que todos los tribunales de justicia del país deban estar organizados de una manera tal que se garantice el derecho fundamental de los justiciables a contar con jueces y tribunales independientes e imparciales.

Para garantizar la debida independencia judicial el poder legislativo debe disponer un adecuado nombramiento de los jueces, de modo tal que no se permita que el poder político tenga influencia sobre las decisiones 
de los jueces. Asimismo, estos jueces no pueden estar a merced del poder político de turno en lo que dice relación con la permanencia en el cargo judicial. Se hace indispensable en esta materia contar con una adecuada regulación del principio de inamovilidad judicial. Hay aspectos de la organización de los tribunales militares en tiempos de paz y de algunos tribunales administrativos chilenos que no permiten sostener que se trata en esos casos de tribunales auténticamente independientes.

La imparcialidad judicial debe permitir que los jueces fallen los asuntos sometidos a su decisión sólo tomando en consideración el criterio establecido en la ley y no su propio interés. Hay aspectos de la justicia penal chilena que podrían hacer pensar que los jueces fallarán haciendo primar su interés antes que el legal. Se trata de algunas hipótesis donde podría operar la denominada fuerza de la prevención, como sucede en aquellos casos regulados por el Código Procesal Penal en que un tribunal dicta una medida cautelar y luego falla el asunto o bien cuando se conocen de apelaciones de medidas cautelares y luego se falla como tribunal de nulidad.

Hay otros aspectos de la justicia chilena donde la doctrina o la propia ley establecen casos de parcialidad del juzgador. Sin embargo, en nuestro criterio no se está frente a hipótesis de parcialidad del juzgador. Un primer aspecto es el de los poderes probatorios oficiosos de los jueces civiles, de familia y laborales. Un sector de la doctrina denuncia que se produciría una afectación de la imparcialidad del juzgador con ellos, tesis que no se debe compartir pues con tales poderes probatorios no hay posibilidad que el juez se decante por una u otra parte, ni menos que le haga surgir un interés en el objeto litigioso.

Un segundo aspecto es el referido a la Ley Orgánica Constitucional del Tribunal Constitucional en la parte que prevé como causal de implicancia el haber emitido opinión con publicidad o dictamen sobre el asunto concreto actualmente sometido al conocimiento del tribunal (artículo 19 LOCTC.). Los jueces constitucionales no pueden estar sujetos a esta causal de implicancia que los hace suponer como parciales para conocer del asunto, puesto que el control constitucional de preceptos jurídicos supone siempre emitir un juicio general de constitucionalidad, al que le es inherente valoraciones políticas e ideológicas. Precisamente un Tribunal Constitucional requiere contar con jueces que de manera previa a su nombramiento emitan juicios políticos o ideológicos, pues se debe tratar de personas que deben haberse destacado en la vida pública, política o académica. Aun más, es necesario que estas personas emitan de manera previa esos juicios para así contar con la información necesaria al momento de su designación por los distintos poderes constitucionales facultados por la Constitución para ello. Esta causal de implicancia debe ser utilizada por el Tribunal Constitucional respecto 
de sus ministros de una manera muy restringida, sin perjuicio de que el legislador debería modificarla hacia el futuro.

En definitiva, el ordenamiento jurídico evidencia algunos problemas con la configuración del derecho fundamental de todas las personas a contar con jueces y tribunales independientes e imparciales. Hay aquí tareas pendientes para el legislador y para el propio Tribunal Constitucional.

[Recibido el 9 de octubre y aceptado el 2 de noviembre de 2009].

\section{BIBLIOGRAFÍA}

AA. VV. Las tensiones entre el Tribunal Constitucional y el Legislador en la Europa actual, AJA, Eliseo (editor) (Barcelona, Ariel, 1998).

Abreu, Alirio, Independencia judicial (jurisprudencia de la Corte Interamericana de Derechos Humanos en Anuario de Derecho Constitucional Latinoamericano, año 13 (2007).

Aldunate, Eduardo, Derechos fundamentales (Santiago de Chile, Legal Publishing, 2008).

AlEXY, Robert, Teoría de los derechos fundamentales (Madrid, Centro de Estudios Constitucionales, 1997).

Alvarado, Adolfo, Imparzialita del giudice e giusto processo en Stato di diritto e garanzie processuali. Atti delle II giornate internazionali di diritto processuale civile, Cipriani, Franco (coordinador) (Nápoles, Edizioni Scientifiche Italiane, 2008).

ANDOLINA, Italo / Vignera, Giuseppe, I fondamenti costituzionali della giustizia civile. Il modelo costituzionale del processo civile italiano ( $2^{\text {a }}$ edición, Turín, Giappichelli, 1997).

Bandrés SÁnchez - CruZat, José Manuel, Derecho fundamental al proceso debido y el Tribunal Constitucional (Pamplona, Aranzadi, 1992).

Bотто, Hugo, Inconstitucionalidad de las medidas para mejor resolver (Santiago de Chile, Editorial Fallos del Mes, 2001).

Bove, Mauro, Artículo 111 cost. E "giusto processo civile", en Rivista di Diritto Processuale, año LVII, 2a serie - No 2, abril - junio (2002).

CHIARLONI, Sergio, Il nuevo articolo 111 della Costituzione e il processo civile en Il nuevo articolo 111 della Costituzione e il giusto processo civile, CIVININI, Maria Giuliana I Verardi, Carlo Maria (editores) (Milán, Franco Angeli, 2001).

Chizzini, Augusto, Brevi spunti in tema di oralità e dimensione retorica nella genesi del processo civile en Audiatur et altera pars. Il contradittorio fra principio e regola, Manzini, Mauricio / Puppo, Federico (Milán, Giuffrè, 2008).

Colmenero, Miguel, La garantía del derecho a un juez imparcial en Persona y Derecho 55 (2006).

Comoglio, Luigi Paolo, Etica e tecnica del "giusto processo" (Turín, Giappichelli, 2004).

DíAz, Regina, Reforma de la justicia militar chilena a la luz de las consideraciones del fallo Palamara: Sentencia Corte Interamericana de Derechos Humanos Palamara Iribarne vs Chile, 22 de noviembre de 2005 en Revista Chilena de Derecho, Vol. 34 No 1 (abril 2007).

Evans, Enrique, Los derechos constitucionales, Tomo II ( $3^{\text {a }}$ edición, Santiago, Editorial Jurídica de Chile, 2004). 
FERnÁndez, Miguel Ángel, Constitución y casación: ¿De la falta de aplicación al monopolio constitucional?, en Estudios Constitucionales, Revista del Centro de Estudios Constitucionales, Chile, año 3 No 1 (2005).

JimÉNEZ AsEnsio, Rafael, imparcialidad judicial y derecho al juez imparcial (Aranzadi, Pamplona, 2002).

Loredo, Marcos, Comentarios prácticos a la Ley de Enjuiciamiento Civil. La imparcialidad en el proceso civil: el deber de abstención. Arts. 99, 100 y 102 a 106 LEC, en INDRET (Mayo 2009).

ManzIN, Maurizio, Del contradittorio como principio e come metodo en Audiatur et altera pars. Il contradittorio fra principio e regola, MANZIN, Maurizio / Puppo, Federico (Milán, Giuffrè, 2008).

Mengozzi, Marta, Giusto processo e processo amministrativo. Profili costituzionali (Milán, Giuffrè, 2009).

Montero Aroca, Juan / Flors, José, Amparo constitucional y proceso civil (2a edición, Valencia, Tirant lo Blanch, 2008).

Nogueira, Humberto, La constitucionalización del proceso: El acceso a la jurisdicción, tutela judicial efectiva o debido proceso, en La constitucionalización del derecho chileno, Ferrada, Juan Carlos (coordinador) (Santiago, Universidad Austral de Chile, Editorial Jurídica de Chile, 2003).

NúNEZ, Manuel Antonio, El control de la igualdad en la aplicación de la ley como factor de expansión del control concreto de constitucionalidad de las leyes en Sentencias destacadas 2007 (Santiago de Chile, Libertad y Desarrollo, 2008).

Palomo, Diego, Proceso civil oral: ¿Qué modelo de juez requiere? en Revista de Derecho, Universidad Austral de Chile, Vol. XVIII - No 1 (julio 2005).

Pedraz, Ernesto, Participación popular en la justicia penal en Revista de Derecho Universidad Austral de Chile, número especial La reforma procesal penal (agosto 1999).

Pedraz, Ernesto, Derecho procesal penal. Tomo I. Principios de Derecho Procesal Penal (Madrid, Colex, 2000).

Perchinunno, Francesco, Fondamento del giusto processo: Dalle origini all attuazione (Bari, Cacucci editore, 2005).

PiCARDI, Nicola, La giurisdizione all alba del terzo milenio (Milán, Giuffrè, 2007).

PICÓ I JunOY, Joan, La iniciativa probatoria del juez penal y el principio acusatorio en Estudios de derecho en homenaje a Raúl Tavolari Oliveros, en Romero Seguel, Alejandro (Santiago de Chile, Universidad de los Andes - LexisNexis, 2007).

Puppo, Federico, La forma retorica del contradittorio en Audiatur et altera pars. Il contradittorio fra principio e regola, MANZINI, Mauricio / PUPPO, Federico (Milán, Giuffrè, 2008).

Roiati, Alessandro, Cause di estromissione personale del giudice e rimessione del processo (Padua, CEDAM, 2007).

TARUFFO, Michele, Investigación judicial y producción de prueba por las partes en Revista de Derecho Universidad Austral de Chile, Vol. XV (diciembre 2003).

TARuffo, Michele, ¿Verdad negociada?, en Revista de Derecho Universidad Austral de Chile, Vol. XXI - No 1 (julio 2008).

Ubertis, Gulio, Principi di procedura penale europea. Le regole del giusto processo (2a edición, Milán, Raffaello Cortina, 2009).

ZANON, Nicoló / BIONDI, Francesca, Il sistema costituzionale della magistratura (Bolonia, Zanichelli, 2006).

ZAPATA, Patricio, Justicia constitucional. Teoría y práctica en el Derecho chileno (Santiago, Editorial Jurídica de Chile, 2008). 